\title{
The Natural Polyphenol Epigallocatechin Gallate Protects Intervertebral Disc Cells from Oxidative Stress
}

\author{
Olga Krupkova, ${ }^{1}$ Junichi Handa, ${ }^{1,2}$ Marian Hlavna, ${ }^{1}$ Juergen Klasen, ${ }^{3}$ \\ Caroline Ospelt, ${ }^{4}$ Stephen John Ferguson, ${ }^{1}$ and Karin Wuertz-Kozak ${ }^{1}$ \\ ${ }^{1}$ Department of Health Sciences and Technology, Institute for Biomechanics, ETH Zurich, Hoenggerbergring 64, \\ 8093 Zurich, Switzerland \\ ${ }^{2}$ Department of Orthopaedic Surgery, Fukushima Medical University School of Medicine, Hikarigaoka, Fukushima City, \\ Fukushima 960-1295, Japan \\ ${ }^{3}$ Prodorso, Walchestrasse 15, 8006 Zurich, Switzerland \\ ${ }^{4}$ Department of Rheumatology, University Hospital, Zurich, Switzerland
}

Correspondence should be addressed to Olga Krupkova; okrupkova@ethz.ch

Received 20 November 2015; Revised 30 January 2016; Accepted 16 February 2016

Academic Editor: Nageswara Madamanchi

Copyright (C) 2016 Olga Krupkova et al. This is an open access article distributed under the Creative Commons Attribution License, which permits unrestricted use, distribution, and reproduction in any medium, provided the original work is properly cited.

\begin{abstract}
Oxidative stress-related phenotypic changes and a decline in the number of viable cells are crucial contributors to intervertebral disc degeneration. The polyphenol epigallocatechin 3-gallate (EGCG) can interfere with painful disc degeneration by reducing inflammation, catabolism, and pain. In this study, we hypothesized that EGCG furthermore protects against senescence and/or cell death, induced by oxidative stress. Sublethal and lethal oxidative stress were induced in primary human intervertebral disc cells with $\mathrm{H}_{2} \mathrm{O}_{2}$ (total $n=36$ ). Under sublethal conditions, the effects of EGCG on p53-p21 activation, proliferative capacity, and accumulation of senescence-associated $\beta$-galactosidase were tested. Further, the effects of EGCG on mitochondria depolarization and cell viability were analyzed in lethal oxidative stress. The inhibitor LY249002 was applied to investigate the PI3K/Akt pathway. EGCG inhibited accumulation of senescence-associated $\beta$-galactosidase but did not affect the loss of proliferative capacity, suggesting that EGCG did not fully neutralize exogenous radicals. Furthermore, EGCG increased the survival of IVD cells in lethal oxidative stress via activation of prosurvival PI3K/Akt and protection of mitochondria. We demonstrated that EGCG not only inhibits inflammation but also can enhance the survival of disc cells in oxidative stress, which makes it a suitable candidate for the development of novel therapies targeting disc degeneration.
\end{abstract}

\section{Introduction}

Degenerative disc disease, characterized by spinal microinstability and lower back pain, is a result of multiple events like age-related degradation of extracellular matrix (ECM), inflammation, or trauma $[1,2]$. During degeneration, the intervertebral disc (IVD) undergoes morphological and functional changes such as calcification of endplates, disruption of annulus fibrosus (AF), and loss of water in the nucleus pulposus (NP), which not only impairs disc function but also decreases nutrient supply and causes accumulation of cellular waste products [3-5]. In such situation, cells can compensate for impaired homeostasis, for example, by activation of neovascularization factors, to enhance the availability of nutrients. However, a catabolic environment and abnormal blood supply in the originally avascular tissue can increase reactive oxygen species (ROS) production and oxidative stress [6-10].

ROS are highly reactive molecules with unpaired electrons formed externally or in mitochondria as a normal part of the aerobic metabolism. To ensure a properly maintained redox balance, organisms require a complex, coordinated network of antioxidants from various sources that control ROS generation [11]. Cellular responses to ROS depend on their concentration and duration of exposure as well as the cell type. As signaling molecules, ROS modulate a variety of physiological events, including proliferation, differentiation, host defense, and wound healing [12]. On the other hand, extensive ROS exposure and/or insufficient cellular antioxidant capacity cause deleterious damage, senescence, and cell death [13]. 
Cellular senescence is described as an irreversible stressinduced cell cycle arrest [14]. Senescence followed by tissue remodeling is beneficial in healthy tissue, where it contributes to the elimination of damaged cells. Furthermore, it is a major protective mechanism against carcinogenesis. However, at the same time, persistent senescence impairs tissue function and leads to inflammation and premature degeneration [15]. Internal DNA damage (telomere shortening) as well as multiple stress signals, including ROS, aberrant oncogene activation, and chemotherapeutic drugs, are able to induce premature senescence via activation of the p53-p21 and/or p16 Ink4a pathway [16]. Although cell and tissue aging has been extensively investigated, the precise mechanisms underlying the development of a senescence phenotype are still unknown [14].

Extensive oxidative stress disrupts the integrity of mitochondria, which can further elicit cell death through three major mechanisms. During apoptosis (1), cytochrome c is released into the cytosol where it activates caspase- 9 , which allows executioner caspases 3, 6, and 7 to cleave their substrates [17]. Caspase-independent cell death mechanisms, such as regulated necrosis (2) or autophagy (3), are equally important in various pathologies, including IVD degeneration $[18,19]$. Similar to senescence, the biological purpose of apoptosis is to eliminate damaged or suboptimal cells [15], although both processes are regulated differently [14]. During apoptosis, a variety of triggers can quickly converge to the executioner effectors through a common mechanism. In contrast, senescence is typically a delayed progressive process, during which various effector mechanisms can each contribute and collectively define the phenotype [14].

The functionality of human IVDs as spinal shockabsorbers gradually decreases throughout lifetime. Senescence of IVD cells, which positively correlates not only with age, but also with the degree of disc degeneration, can be linked to oxidative stress [10, 20-27]. Oxidative stressinduced senescence and death of IVD cells contribute to the local tissue inflammation and the expression of matrix degrading enzymes, hence accelerating loss of proteoglycans [28]. Extensive production of mitochondrial ROS during IVD cell death may further impair disc tissue homeostasis [6, 19, 29-31]. Apart from oxidative stress, also other factors, like nonphysiological mechanical loading, an acidic environment, or autoimmune reactions, can alter the cellular phenotype and enhance premature senescence and cell death in the IVD $[25,32,33]$.

Despite the fact that IVD degeneration and back pain represent an economic burden, only symptomatic therapies, like analgesics or invasive surgeries, are currently available. Such therapies do not target the biological causes of disc degeneration and either offer only temporary relief or entail risks and complications. The focus of the current research is to restore the disc function via prevention of premature aging, inhibition of cell death, and enhancement of ECM maintenance with an ultimate goal to prevent low back pain $[4,34]$. One approach to compensate the loss of functional disc cells is to apply stem cells embedded in diverse biomaterials mimicking disc tissue, which may support the old disc population and "rejuvenate" the aging disc. However, the implanted cells can in some cases undergo incorrect differentiation, can induce inflammatory reactions, and may not survive due to a prior catabolic environment $[35,36]$. Another approach is to enhance survival of the existing intrinsic disc cells using various pharmacological agents such as growth factors or inhibitors of inflammatory pathways [4, 37].

We have previously shown that epigallocatechin 3-gallate (EGCG), a polyphenol naturally occurring in green tea, inhibits inflammatory responses in IVD cells in vitro and exhibits analgesic activity against disc-related radiculopathy in experimental animals [38]. The aim of this in vitro study was to (1) further investigate whether EGCG exhibits protective effects in mild and high oxidative stress and to (2) investigate the molecular mechanism involved.

\section{Methods}

2.1. DPPH Radical Scavenging Activity Assay. Antioxidant activity of EGCG was determined by measuring its scavenging capacity of the $2,2^{\prime}$-diphenyl-1-picrylhydrazyl (DPPH) radical as previously described [39]. $100 \mu \mathrm{L}$ of $10-300 \mu \mathrm{M}$ EGCG was incubated with $500 \mu \mathrm{L}$ of DPPH $(250 \mu \mathrm{M}$ in ethanol; D9132 Sigma, Buchs, Switzerland) for 1 hour at room temperature $(n=3)$. DPPH radical scavenging activity, which manifests itself as a decrease in absorbance, was measured at $517 \mathrm{~nm}$ with a spectrophotometer (Infinite M200 PRO, TECAN Group AG, Männedorf, Switzerland). L-Ascorbic acid (A4403, Sigma) and ethanol (02860, Sigma) in equal amounts were used as positive and negative control, respectively. DPPH radical scavenging activity (\%) was calculated as [negative control optical density (OD) - sample OD] * 100/negative control OD.

2.2. Cell Isolation and Cell Culture. The study was approved by the cantonal ethic committee (Kantonale Ethikkommission Zürich EK-16/2005). After informed consent was granted, human NP tissue (grades III-V) was removed from donors undergoing spinal surgeries for degenerative disc disease or disc herniation $(n=36)$. Details about the donors for this study are listed in Table 1. The tissue was enzymatically digested using a mixture of $0.2 \%$ collagenase NB4 (17454, Serva, Heidelberg, Germany) and 0.3\% dispase II (04942078001, Roche, Basel, Switzerland) for 4-8 hours at $37^{\circ} \mathrm{C}$ and isolated primary cells were seeded in Dulbecco's Modified Eagle's Medium (DMEM/F12, D8437, Sigma, St. Louis, MO, USA), supplemented with $10 \%$ fetal calf serum (FCS, F7524, Sigma), penicillin (50 units/mL), streptomycin (50 $\mu \mathrm{g} / \mathrm{mL})$, and ampicillin (125 ng/mL, 15240-062, Gibco, Carlsbad, CA, USA) and subcultured up to passage 3 using $1.5 \%$ trypsin (15090-046, Gibco). Adherent cells in passages 1-3 were used for experiments. Due to the small biopsy size, low proliferation rate, and dedifferentiation of primary IVD cells in monolayer, a single donor cannot be used for all required experiments. Therefore, different donors were randomly assigned to the specific experiments. Cells were seeded on 6 -well plates at a density of $1 \times 10^{5}$ cells per well for all senescence experiments. Cells were seeded on 12-well plates at a density of $1 \times 10^{5}$ cells per well for all lethal oxidative stress experiments, except JC-1 staining assay, which was 
TABLE 1: Intervertebral disc pathologies used for primary cell cultures.

\begin{tabular}{|c|c|c|c|c|}
\hline \multicolumn{3}{|c|}{ Donor information } & \multicolumn{2}{|c|}{ Experiments } \\
\hline Number & Gender, age & $\begin{array}{c}\text { Level } \\
\text { pathology, grade }\end{array}$ & Sublethal oxidative stress & Lethal oxidative stress \\
\hline 1 & M, 35 & $\begin{array}{c}\text { L4/L5 } \\
\text { Herniation IV }\end{array}$ & $\begin{array}{c}\mathrm{H}_{2} \mathrm{O}_{2} \text { sensitivity study, p21 time course } \\
\text { Senescence validation } \\
10 \text { days: additive effect }\end{array}$ & $\begin{array}{c}\mathrm{H}_{2} \mathrm{O}_{2} \text { sensitivity study } \\
\text { PI/A }\end{array}$ \\
\hline 2 & F, 77 & $\begin{array}{c}\text { L4/L5 } \\
\text { DDD III }\end{array}$ & $\begin{array}{l}\text { p21 time course } \\
10 \text { days: additive effect }\end{array}$ & JC-1, MTT \\
\hline 3 & F, 53 & $\begin{array}{l}\text { L4/L5 } \\
\text { DDD IV }\end{array}$ & $\begin{array}{c}\mathrm{H}_{2} \mathrm{O}_{2} \text { sensitivity study, p21 time course } \\
\text { Senescence validation } \\
10 \text { days: additive effect }\end{array}$ & $\begin{array}{c}\mathrm{H}_{2} \mathrm{O}_{2} \text { sensitivity study } \\
\mathrm{PI} / \mathrm{A}, \mathrm{MTT}\end{array}$ \\
\hline 4 & F, 39 & $\begin{array}{c}\text { L5/S1 } \\
\text { Herniation V }\end{array}$ & $\begin{array}{l}\mathrm{H}_{2} \mathrm{O}_{2} \text { sensitivity study } \\
\text { Senescence validation } \\
10 \text { days: antioxidant }\end{array}$ & $\begin{array}{c}\mathrm{H}_{2} \mathrm{O}_{2} \text { sensitivity study } \\
\text { PI/A, MTT }\end{array}$ \\
\hline 5 & $\mathrm{~F}, 31$ & $\begin{array}{c}\text { L4/L5 } \\
\text { Herniation uk }\end{array}$ & $\begin{array}{l}\mathrm{H}_{2} \mathrm{O}_{2} \text { sensitivity study } \\
\text { Senescence validation }\end{array}$ & $\begin{array}{c}\mathrm{H}_{2} \mathrm{O}_{2} \text { sensitivity study } \\
\text { JC-1, PI/A, MTT }\end{array}$ \\
\hline 6 & F, 64 & $\begin{array}{l}\text { L4/L5 } \\
\text { DDD III }\end{array}$ & $\begin{array}{l}\mathrm{H}_{2} \mathrm{O}_{2} \text { sensitivity study } \\
\text { Senescence validation }\end{array}$ & $\begin{array}{c}\mathrm{H}_{2} \mathrm{O}_{2} \text { sensitivity study } \\
\text { JC-1, PI/A, MTT }\end{array}$ \\
\hline 7 & F, 53 & $\begin{array}{c}\text { L5/S1 } \\
\text { Herniation IV }\end{array}$ & - & JC-1 \\
\hline 8 & $\mathrm{M}, 50$ & $\begin{array}{c}\text { L4/5 } \\
\text { DDD III }\end{array}$ & - & JC-1 \\
\hline 9 & F, 54 & $\begin{array}{c}\text { L5/S1 } \\
\text { Herniation V }\end{array}$ & 10 days: recovery, RT qPCR & - \\
\hline 10 & M, 64 & $\begin{array}{c}\text { L5/S1 } \\
\text { Herniation III }\end{array}$ & 10 days: recovery, RT qPCR & - \\
\hline 11 & M, 44 & $\begin{array}{l}\text { L5/S1 } \\
\text { Her IV }\end{array}$ & 10 days: antioxidant, RT qPCR & - \\
\hline 12 & M, 56 & $\begin{array}{c}\text { L4/L5 } \\
\text { Herniation III }\end{array}$ & 10 days: recovery, RT qPCR & - \\
\hline 13 & F, 51 & $\begin{array}{c}\text { C4/5 } \\
\text { Herniation III }\end{array}$ & 10 days: antioxidant & - \\
\hline 14 & F, 42 & $\begin{array}{c}\text { L3/L4 } \\
\text { Herniation III }\end{array}$ & 10 days: antioxidant & - \\
\hline 15 & F, 35 & $\begin{array}{c}\text { L5/S1 } \\
\text { DDD, Herniation IV }\end{array}$ & 10 days: recovery & - \\
\hline 16 & $\mathrm{M}, 41$ & $\begin{array}{l}\text { L4/L5 } \\
\text { DDD III }\end{array}$ & 10 days: additive effect & - \\
\hline 17 & M, 40 & $\begin{array}{c}\text { L5/S2 } \\
\text { DDD, Herniation V }\end{array}$ & 10 days: antioxidant & - \\
\hline 18 & $\mathrm{M}, 50$ & $\begin{array}{c}\text { L4/L5 } \\
\text { DDD, Herniation III }\end{array}$ & 10 days: additive effect & - \\
\hline 19 & F, 42 & $\begin{array}{c}\text { L3/L4 } \\
\text { Herniation III }\end{array}$ & 10 days: recovery & - \\
\hline 20 & $M, 43$ & $\begin{array}{c}\mathrm{L} 5 / \mathrm{S} 1 \\
\mathrm{DDD}, \mathrm{uk}\end{array}$ & - & JC-1, bright field, MTT, MTT (I) \\
\hline 21 & F, 51 & $\begin{array}{l}\text { L4/L5 } \\
\text { DDD IV }\end{array}$ & - & JC-1, bright field, MTT, MTT (LY), MTT (I) \\
\hline 22 & $\mathrm{M}, 47$ & $\begin{array}{c}\text { L4/L5 } \\
\text { DDD, Herniation III }\end{array}$ & - & JC-1, bright field, MTT \\
\hline 23 & F, 44 & $\begin{array}{l}\text { L4/L5 } \\
\text { DDD III }\end{array}$ & - & JC-1, bright field, MTT, MTT (LY), MTT (I) \\
\hline 24 & F, 43 & $\begin{array}{c}\text { L5/S1 } \\
\text { DDD, Herniation III }\end{array}$ & - & JC-1, bright field, MTT, MTT (LY), MTT (I) \\
\hline 25 & $\mathrm{M}, 47$ & $\begin{array}{c}\mathrm{L} 4 / 5 \\
\text { DDD, Herniation III }\end{array}$ & - & Lethal: MTT (LY), MTT (I) \\
\hline
\end{tabular}


TABle 1: Continued.

\begin{tabular}{|c|c|c|c|c|}
\hline \multicolumn{3}{|c|}{ Donor information } & \multicolumn{2}{|c|}{ Experiments } \\
\hline Number & Gender, age & $\begin{array}{c}\text { Level } \\
\text { pathology, grade }\end{array}$ & Sublethal oxidative stress & Lethal oxidative stress \\
\hline 26 & M, 39 & $\begin{array}{c}\mathrm{L} 4 / 5 \\
\text { DDD, Herniation IV }\end{array}$ & - & Lethal: MTT (LY), MTT (I) \\
\hline 27 & $\mathrm{M}, 21$ & $\begin{array}{c}\text { L5/S1 } \\
\text { Herniation III }\end{array}$ & - & Lethal: MTT (LY), MTT (I) \\
\hline 28 & F, 43 & $\begin{array}{c}\mathrm{L} 4 / 5 \\
\text { DDD, Herniation IV }\end{array}$ & - & Lethal: MTT (LY), MTT (I) \\
\hline 29 & M, 33 & $\begin{array}{c}\text { L5/S1 } \\
\text { Herniation III }\end{array}$ & - & Lethal: WB \\
\hline 30 & F, 39 & $\begin{array}{c}\text { L5/S1 } \\
\text { DDD, Herniation III }\end{array}$ & - & Lethal: MTT (LY), WB, MTT (I) \\
\hline 31 & F, 39 & $\begin{array}{c}\text { L4/5 } \\
\text { DDD, Herniation IV }\end{array}$ & - & Lethal: MTT (LY), WB, MTT (I) \\
\hline 32 & uk & uk & - & Lethal: MTT (LY), WB \\
\hline 33 & $\mathrm{M}, 55$ & $\begin{array}{c}\text { L3/4 } \\
\text { DDD III }\end{array}$ & - & Lethal: WB \\
\hline 34 & F, 56 & $\begin{array}{c}\text { L3/4 } \\
\text { Herniation IV }\end{array}$ & - & Lethal: MTT (LY), WB \\
\hline 35 & M, uk & $\begin{array}{c}\mathrm{L} 4 / 5 \\
\text { Herniation uk }\end{array}$ & - & Lethal: MTT (LY) \\
\hline 36 & uk & uk & - & Lethal: MTT (LY) \\
\hline
\end{tabular}

DDD: degenerative disc disease, PI/A: Propidium Iodide/Annexin staining, MTT: MTT assay, MTT (LY): MTT assay with LY, MTT (I): MTT assay with insulin, and uk: unknown.

TABLE 2: Experimental design.

\begin{tabular}{lccl}
\hline & \multicolumn{2}{c}{ Sublethal oxidative stress, induction of premature senescence } \\
Experimental setup & Stress phase (2 hours) & Recovery phase (up to 15 days) & Tested EGCG effect \\
\hline (1) Antioxidant & $50 \mu \mathrm{M} \mathrm{H}_{2} \mathrm{O}_{2}+10 \mu \mathrm{M} \mathrm{EGCG}$ & - & $\begin{array}{l}\text { ROS neutralization } \\
\text { Interaction with poststress signaling } \\
\text { (e.g., changes in gene expression) } \\
\text { (2) Recovery }\end{array}$ \\
$50 \mu \mathrm{M} \mathrm{H}_{2} \mathrm{O}_{2}$ & $+10 \mu \mathrm{M}$ EGCG & $\begin{array}{l}\text { ROS neutralization } \\
\text { Interaction with poststress signaling }\end{array}$ \\
(3) Combined & $50 \mu \mathrm{M} \mathrm{H}_{2} \mathrm{O}_{2}+5 \mu \mathrm{M}$ EGCG & $+5 \mu \mathrm{M}$ EGCG & Tested EGCG effect \\
\hline Experimental setup & Lethal oxidative stress, cell death induction & Prosurvival \\
(1) Survival & Stress phase $(24$ hours) & Antioxidant \\
\hline
\end{tabular}

performed on 6-well plates. After seeding, cells were left to adhere overnight.

2.3. Experimental Design and Treatments. Oxidative stress was induced with $\mathrm{H}_{2} \mathrm{O}_{2}$ (V800211, Sigma), which initiates the generation of ROS that are able to attack all types of biomolecules $[40,41]$. The active concentration of $\mathrm{H}_{2} \mathrm{O}_{2}$ was selected based on the results of a preliminary $\mathrm{H}_{2} \mathrm{O}_{2}$ sensitivity study $(n=5)$. Increasing concentrations of $\mathrm{H}_{2} \mathrm{O}_{2}$ (10$200 \mu \mathrm{M})$ were applied for 24 hours and cellular responses were tested by MTT assay. The lethal concentration of $\mathrm{H}_{2} \mathrm{O}_{2}$ (100 $\mu \mathrm{M}$ and $200 \mu \mathrm{M}$ for 24 hours) as well as the sublethal concentration of $\mathrm{H}_{2} \mathrm{O}_{2}$ which can induce senescent changes without significant cell death $\left(50 \mu \mathrm{M} \mathrm{H} \mathrm{H}_{2} \mathrm{O}_{2}\right.$ applied for 2 hours, followed by recovery period) were identified. FCS-free media were used during all oxidative stress treatments to rule out the possible interaction of radicals with FCS components. Previously reported nontoxic EGCG concentrations $(5 \mu \mathrm{M}$ and $10 \mu \mathrm{M}$ ) were applied in this study [38].

The effect of EGCG (E4143, Sigma) on premature senescence was tested in three different experimental setups to identify mechanism of EGCG's action (Table 2): (1) to test its antioxidant activity, $10 \mu \mathrm{M}$ EGCG was applied in the stress phase simultaneously with $\mathrm{H}_{2} \mathrm{O}_{2}$, (2) to test its effects on poststress processes, $10 \mu \mathrm{M}$ EGCG was added only in the recovery phase, and (3) to combine its potential benefits in both phases, $5 \mu \mathrm{M}$ EGCG was added in the stress phase and later again in the recovery phase.

The effect of $10 \mu \mathrm{M}$ EGCG on cell death was tested directly in the stress phase, without recovery period (Table 2). To 
further test the involved mechanism, LY294002, an inhibitor of the PI3K/protein kinase B (Akt) pathway (LY, L9908, Sigma), was applied at a concentration of $10 \mu \mathrm{M}$, along with EGCG $(n=10)$. PI3K/Akt activator insulin (I9278, Sigma) was used at a concentration of $0.5 \mu \mathrm{L} / \mathrm{mL}$ to confirm functionality and specificity of LY in our experiments $(n=$ $10)$.

2.4. In Vitro Model System of Premature Senescence. Premature senescence was induced with sublethal $\mathrm{H}_{2} \mathrm{O}_{2}$. After seeding, cells were starved in FCS-free medium for 2 hours before applying $50 \mu \mathrm{M} \mathrm{H}_{2} \mathrm{O}_{2}$ for another 2 hours. As a next step, media were replaced by complete media $(+10 \%$ FCS) to let the cells recover from oxidative stress. Premature senescence was monitored for 15 days with media exchange on days 5 and 10 . To verify senescence-associated changes, various tests were performed: senescence-associated $\beta$-galactosidase activity was tested on days $1,5,10$, and 15 after stress $(n=5)$. The number of viable cells was determined by Trypan blue exclusion test on days 8 and $15(n=5)$. Cellular metabolic activity was measured by MTT assay and expression/activity of senescence-associated proteins p 21 and p 53 was analyzed by immunoblotting on day $15(n=5)$. In a separate experiment on day 8 , trypsin-detached cells were reseeded again to check their ability to adhere, which reflects general cellular fitness.

2.5. Senescence-Associated SA $\beta$-galactosidase Assay. Senescence-associated $\beta$-galactosidase (SA $\beta$-gal), which accumulates in aging cells, serves as a reliable marker of senescence in vitro [42]. Senescence was induced with $50 \mu \mathrm{M} \mathrm{H}_{2} \mathrm{O}_{2}$, followed by EGCG treatments as described above $(n=5$ for each experimental setup). For SA $\beta$-gal analysis, staining solution containing $40 \mathrm{mM} \mathrm{Na}_{3}$ citrate $\times 2 \mathrm{H}_{2} \mathrm{O}+5 \mathrm{mM} \mathrm{K}_{4} \mathrm{Fe}(\mathrm{CN})_{6}$ $+5 \mathrm{mM} \mathrm{K}_{3} \mathrm{Fe}(\mathrm{CN})_{6}+0.15 \mathrm{M} \mathrm{NaCl}+2 \mathrm{mM} \mathrm{MgCl}_{2}$ in $\mathrm{H}_{2} \mathrm{O}$ was prepared and its $\mathrm{pH}$ was adjusted to 6 by adding $0.5 \mathrm{M}$ $\mathrm{NaH}_{2} \mathrm{PO}_{4}$ (all from Sigma). X-gal (11680293, Roche) was dissolved in dimethylformamide (33120, Sigma) to prepare a $20 \mathrm{mg} / \mathrm{mL}$ stock solution. Adherent cells were washed twice with PBS and fixed with 3\% paraformaldehyde (30525894, Acros, Geel, Belgium) in PBS for 5 minutes at room temperature. After the fixation, cells were washed twice with PBS and a mixture of X-gal + staining solution in a 1:20 ratio was added. After 18 hours, the staining solution was removed and cells were washed two times in distilled water and passed through graded ethanol (75\%, 95\%, 99\%), 1 minute each. After air-drying, micrographs were taken from 3 random spots of each well using light microscopy. The number of all cells (minimum 300) and SA $\beta$-gal positive cells was counted by processing images with GIMP (http://www.gimp.org/) and ImageJ (http://imagej.nih.gov/ij/). The percentage of SA $\beta$-gal positive cells in each treatment group was calculated as the number of SA $\beta$-gal positive cells/number of all cells * 100. SA $\beta$-gal positive cells in the treatment groups were displayed relative to the control groups, due to the high interdonor variability in basal SA $\beta$-gal staining.

2.6. Trypan Blue Exclusion Test. Trypan blue staining, which distinguishes viable and dying cells, was performed to analyze the total number of viable cells at the end of each experiment. Senescence was induced with $50 \mu \mathrm{M} \mathrm{H}_{2} \mathrm{O}_{2}$ and EGCG treatments were performed as described above $(n=$ 5 for each experimental setup). Cells were harvested using $1.5 \%$ trypsin into the complete media, an aliquot was mixed $1: 1$ with $0.4 \%$ Trypan blue dye (93595, Fluka), and the cell suspension was immediately analyzed on the grids of the hemacytometer (DHC-N01, Thermo Scientific). The absolute number of nonstained (viable) cells was determined in each group to make a comparison with the total number of seeded cells $\left(1 \times 10^{5}\right.$ cells per well). Nonviable cells, which took up Trypan blue dye, were excluded from the analysis.

2.7. Metabolic Activity Measurement. Metabolic activity, which reflects cellular viability, was determined using the MTT assay. Following seeding, sublethal or lethal oxidative stress was applied and the treatments were performed as described above ( $n=5$ for sublethal oxidative stress experiments, $n=10$ for lethal oxidative stress experiment, and $n=10$ for inhibition experiments). After 24 hours or 10 days, fresh MTT (3-[4,5-dimethylthiazol-2-yl]-2,5-diphenyl tetrazolium bromide, M5655, Sigma) solution in PBS $(0.5 \mathrm{mg} / \mathrm{mL})$ was added and kept for 3 hours at $37^{\circ} \mathrm{C}$. MTT was discarded, cells were lysed in DMSO (D8418, Sigma), and the absorbance was measured at $565 \mathrm{~nm}$. Metabolic activity was calculated relative to the untreated control (100\%).

2.8. Immunoblotting. Treatments were performed as described above. Cells were harvested after 15 min treatment for lethal oxidative stress experiments $(n=5)$ or after 10 days and 15 days for sublethal oxidative stress experiments $(n=5)$. Whole cell lysates were prepared in RIPA buffer (89900, Thermo Scientific, Waltham, MA, USA) according to the producer's instructions, mixed with Laemmli buffer (S3401, Sigma), heated $\left(99^{\circ} \mathrm{C}, 5\right.$ minutes), and then loaded onto $12 \%$ SDS polyacrylamide gels. Separated proteins were transferred onto polyvinylidene difluoride (PVDF) membranes (RPN303F, GE Healthcare, Little Chalfont, UK) and membranes were blocked in 5\% nonfat milk in Tris-buffered saline-Tween (TBS-T) for 1 hour at room temperature. Primary antibodies were applied overnight at $4^{\circ} \mathrm{C}$. After washing in $1 \%$ nonfat milk in TBS-T $(3 \times 10 \mathrm{~min})$, membranes were incubated with a secondary antibody conjugated to horseradish peroxidase (HRP) for 1 hour at room temperature and washed in $1 \%$ nonfat milk in TBS-T $(3 \times 10 \mathrm{~min})$. Visualization was performed on medical X-ray film (28906836, GE Healthcare), using a chemiluminescence kit West Dura (34076, Thermo Scientific). Tubulin was used as a loading control. Antibodies and dilutions were as follows: phospho-p53 (Ser15) 1:1000 (9284, Cell Signaling, Danvers, MA, USA); p21 1:1000 (2947, Cell Signaling); phospho-Akt (Ser473) 1: 1000 (9271, Cell Signaling); Akt 1:1000 (9272, Cell Signaling); p16 Ink4a (p16) 1:1000 (ab108349, Abcam); $\alpha$ Tubulin 1:1000 (2144, Cell Signaling); and mouse anti-rabbit IgG HRP 1:5000 (7074, Cell Signaling).

2.9. Analysis of Mitochondrial Transmembrane Potential (JC-1 Staining). JC-1 fluorochrome $\left(5,5^{\prime}, 6,6^{\prime}\right.$-tetrachloro-1, $1^{\prime}, 3,3^{\prime}$ tetraethylbenzimidazolcarbocyanine iodide) allows for 
monitoring changes in mitochondrial transmembrane potential, which precedes cell death. In physiological conditions, JC-1 accumulates in the intact mitochondrial membrane, where it forms pronounced red aggregates. Once mitochondrial membrane potential is disturbed, the red fluorescence decreases, which is accompanied by an increase in green fluorescence of the free JC-1 form. A substantial increase in the green fluorescence $(=$ reduced red/green ratio) suggests a breakdown of mitochondrial potential and activation of cell death.

Lethal oxidative stress was applied and EGCG treatment was performed as described above $(n=10)$. After 24 hours, $1 \mu \mathrm{g} / \mathrm{mL}$ of JC-1 (T0046, Chemodex, St. Gallen, Switzerland) diluted in FCS-free media was added to the cells and kept at $37^{\circ} \mathrm{C}$ in the dark for 30 minutes. Then, cells were washed $(3 \times$ PBS $)$ and images of 3 random spots per well were taken immediately with a fluorescence microscope (Olympus IX51, Volketswil, Switzerland). The ratio of red/green fluorescence was calculated using ImageJ analysis (http://imagej.nih.gov/ij/).

2.10. Propidium Iodide/Annexin V-FITC Staining. The membrane of living cells is impermeable for Propidium Iodide (PI), a red fluorescent dye which intercalates into DNA. Annexin V-FITC (A) binds membrane phosphatidylserine, which is exposed to the extracellular environment as one of the early apoptotic events. Flow cytometry analysis of PI/A staining allows distinguishing viable cells (PI-negative/Anegative), cells in early apoptosis (PI-negative/A-positive), and dead cells (PI-positive/A-positive) [43].

Lethal oxidative stress was applied and EGCG treatment was performed as described above $(n=5)$. After 24 hours, supernatants were collected into prechilled tubes and placed on ice. Cells were washed with PBS, detached from cell culture wells with $1.5 \%$ trypsin, and transferred into the corresponding prechilled tubes with matching supernatants. All the further steps were performed on ice. Cell-supernatant mixtures were centrifuged $\left(250 \times \mathrm{g} / 5 \mathrm{~min}, 4^{\circ} \mathrm{C}\right)$, supernatants were discarded, and $400 \mu \mathrm{L}$ of Annexin Binding Buffer (556454, BD Biosciences, Franklin Lakes, NJ, US) was added to the pellets and mixed. After the addition of $1 \mu \mathrm{L}$ of PI (556463, BD Biosciences) and $2.5 \mu \mathrm{L}$ of Annexin (556420, BD Biosciences), tubes were kept in the dark for 15 minutes. Flow cytometry was performed immediately using the cytometer FACS ARIA III (BD Biosciences). Results were analyzed with FlowJO (http://www.flowjo.com/) and are displayed as percentage of viable cells $\left(\mathrm{PI}^{-} / \mathrm{A}^{-}\right)$in each treatment group. Unstained cells, cells stained with Annexin V-FITC alone, and cells stained with PI alone were used as controls to set up quadrants.

2.11. Gene Expression Analysis (RT-qPCR). The effect of sublethal oxidative stress on the activation of senescenceassociated secretory phenotype (SASP) was tested by means of gene expression of interleukin-6 (IL-6), interleukin8 (IL-8), matrix metalloproteinase 1 (MMP1), matrix metalloproteinase 3 (MMP3), and matrix metalloproteinase 13 (MMP13). These genes are typically expressed in a proinflammatory and catabolic environment during inflammation-related disc degeneration [44, 45]. IVD cells were seeded on 6-well plates and senescence was induced as described above $(n=4)$. After 24 hours, RNA was extracted with the Trizol/chloroform method according to the manufacturer's instructions (15596-018, Invitrogen, Carlsbad, CA, USA) and $1 \mu \mathrm{g}$ was reverse transcribed to cDNA using a reverse transcription kit (4374966, Applied Biosystems). cDNA was then mixed with primers and master mix (4352042, Applied Biosystems) and gene expression was measured using real-time PCR. The following primers were used: TATA box binding protein (TBP) Hs00427620_m1, IL-6 Hs00174131_m1, IL-8 Hs00174103_m1, MMP1 Hs00233958_m1, MMP3 Hs00968308_m1, and MMP13 Hs00233992_ml. Data was analyzed with the comparative Cq method $\left(2^{-\Delta \Delta \mathrm{Cq}}\right.$, housekeeping gene TBP). Results are presented as a fold change relative to the untreated control group.

2.12. Statistical Analysis. A power calculation ( $80 \%$ power) determined the required sample size $(n=5)$. Data normality was tested by Schapiro-Wilk test. Statistical significance between two groups was analyzed using Student's $t$-test. Statistical significance between more than two groups was evaluated by ANOVA with Tukey post hoc test. The number of donors used for each experiment is listed in Methods. Mean and SEM are displayed in graphs and asterisks represent a significance level of $p<0.05$.

\section{Results}

3.1. Validation of the In Vitro Model System of Premature Senescence of IVD Cells. Based on the sensitivity study, 50 $\mu \mathrm{M} \mathrm{H} \mathrm{H}_{2} \mathrm{O}_{2}$ applied for 2 hours and followed by a recovery period up to 15 days was chosen to induce premature senescence of IVD cells without significant cell death (Supplementary Figure 1 in Supplementary Material available online at http://dx.doi.org/10.1155/2016/7031397). Analysis of senescence-associated changes was performed on days 1, 5, 8,10 , and 15 after stress. In the $\mathrm{H}_{2} \mathrm{O}_{2}$ treatment group, the number of SA $\beta$-gal positive cells increased significantly from day $1(12.67 \pm 2.05 \%)$ up to day $15(49.53 \pm 4.58 \%)$ after stress, compared with the untreated controls (Figure 1(a)). Representative images of SA $\beta$-gal staining on day 8 and reseeded cells on day 9 are shown (Figure 1(b)). Reseeded cells in the $\mathrm{H}_{2} \mathrm{O}_{2}$ treatment group were able to adhere, which confirmed a good general cellular fitness; however, altered cellular morphology suggested an aging cell population.

Phosphorylation of the stress-induced protein p53 (Ser15) and enhanced expression of the cell cycle inhibitor p21 on day 15 in the $\mathrm{H}_{2} \mathrm{O}_{2}$ treatment group indicated oxidative damage (Figure 1(c)). In order to compare the replicative potential of stressed and control cells, the living cells were counted on days 8 and 15 by Trypan blue exclusion test. The cell number on day 8 in the $\mathrm{H}_{2} \mathrm{O}_{2}$ group $\left(1.53 \pm 0.16 \times 10^{5}\right.$ cells/well $)$ was significantly lower than in the control group $(2.63 \pm$ $0.18 \times 10^{5}$ cells/well), confirming oxidative stress-induced loss of proliferative capacity. Cell death in the $\mathrm{H}_{2} \mathrm{O}_{2}$ group on day 8 did not occur, as the number of cells was higher than 


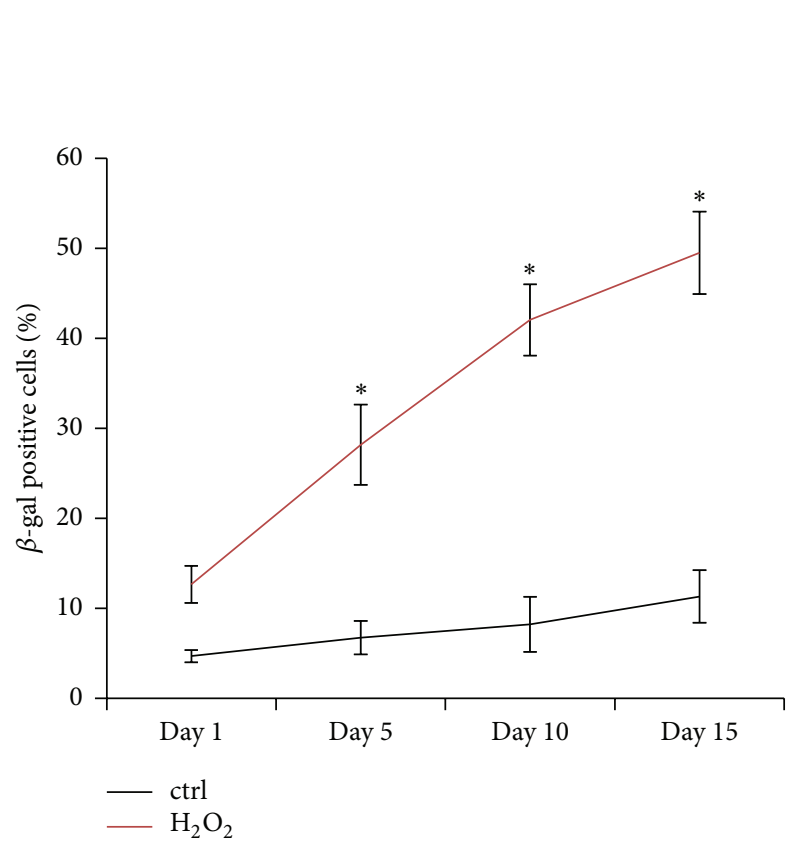

(a)

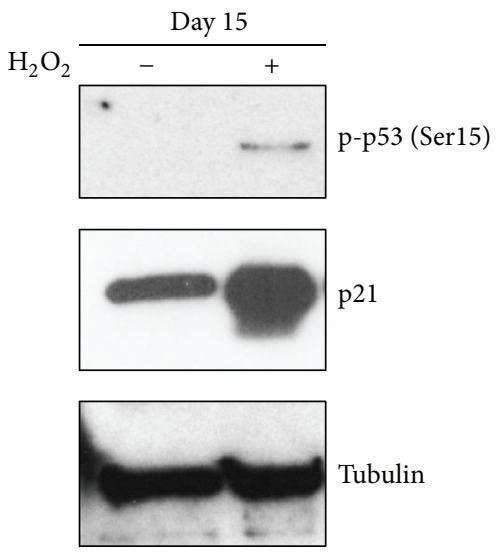

(c)
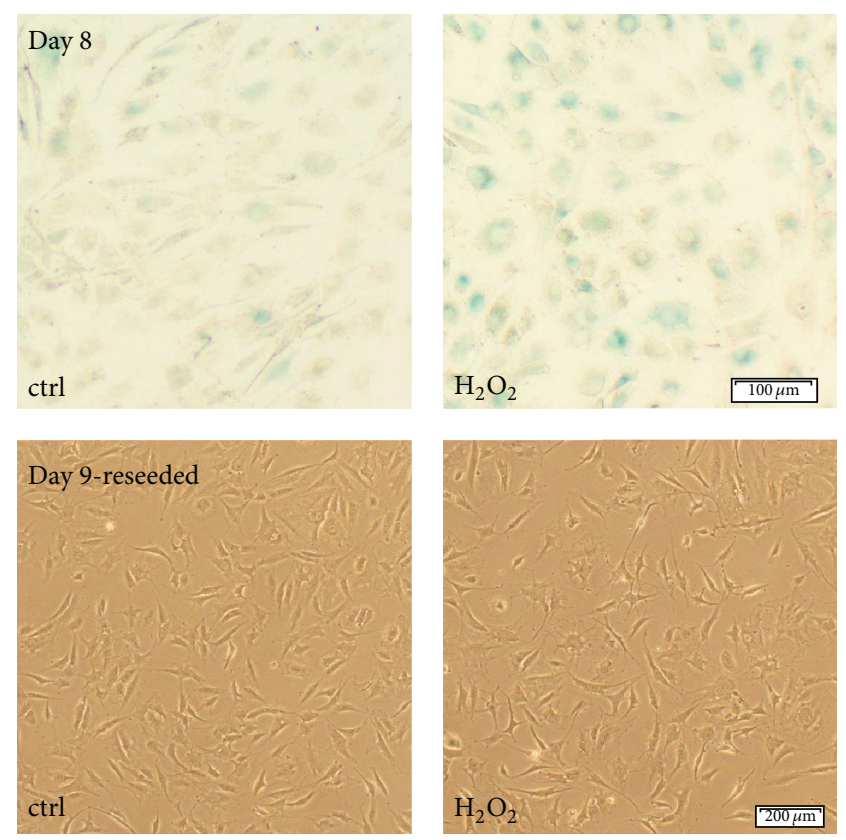

(b)

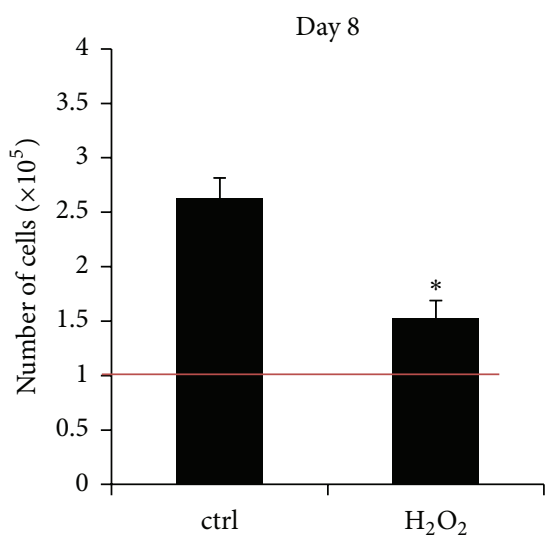

(d)

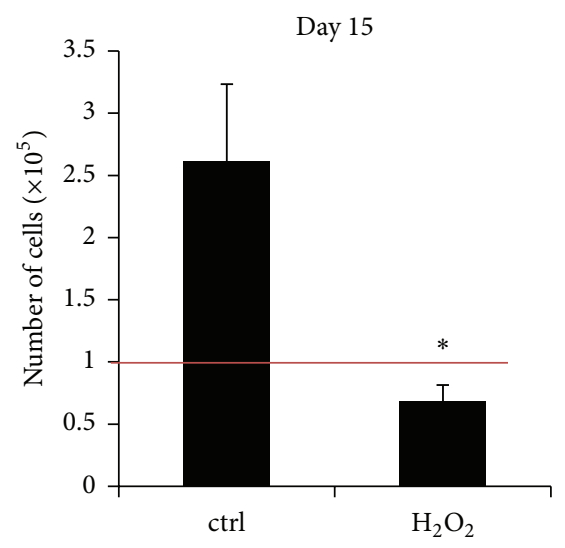

(e)

FIGURE 1: In vitro model system of stress-induced premature senescence. Sublethal oxidative stress $\left(50 \mu \mathrm{M} \mathrm{H}_{2} \mathrm{O}_{2}\right)$ with subsequent recovery period activated premature senescence of IVD cells in vitro. (a) Percentage of SA $\beta$-gal-positive cells in the $\mathrm{H}_{2} \mathrm{O}_{2}$ treatment group gradually increased during 15 days after stress $(n=5)$. (b) Upper part: representative images of SA $\beta$-gal staining of the untreated $(c t r l)$ and the $\mathrm{H}_{2} \mathrm{O}_{2}$ treated cells on day 8 after stress, showing senescent (blue) cells. (b) Lower part: representative images of reseeded cells on day 9, confirming general cellular fitness. (c) Phosphorylation of p53 (Ser15) and expression of p21 in the $\mathrm{H}_{2} \mathrm{O}_{2}$ treatment group on day 15 after stress indicated cellular senescence. ((d), (e)) Proliferative capacity, displayed as number of cells on days 8 and 15 after stress, was reduced in the $\mathrm{H}_{2} \mathrm{O}_{2}$ groups. On day 15, the number of cells in the $\mathrm{H}_{2} \mathrm{O}_{2}$ treatment group decreased below the seeding number $\left(1 \times 10^{5}\right.$ cells per well, depicted as red line), suggesting ongoing cell death. Asterisks indicate statistical significance at $p<0.05$ (ANOVA, Tukey post hoc, and Student's $t$-test).

the cell seeding density on day $0\left(1 \times 10^{5}\right.$ cells/well, marked as red line) (Figure $1(\mathrm{~d})$ ). However, on day 15, the number of cells in the $\mathrm{H}_{2} \mathrm{O}_{2}$ treatment group decreased below the seeding density $\left(0.68 \pm 0.13 \times 10^{5}\right.$ cells/well versus $1 \times$ $10^{5}$ cells/well, marked as red line), indicating that the cells slowly started to die from the ROS exposure (Figure $1(\mathrm{e})$ ). As cell death may hamper data interpretation, all subsequent experiments were performed for a maximum of 10 days.

The expression of inflammatory genes in the $\mathrm{H}_{2} \mathrm{O}_{2}$ treatment group, measured on day 1, was not significantly elevated (Supplementary Figure 1).
3.2. EGCG Inhibited Senescence-Associated $\beta$-galactosidase Accumulation in Sublethal Oxidative Stress. Previously reported antioxidant properties of EGCG were confirmed using 2,2-diphenyl-1-picrylhydrazyl (DPPH) radical assay. EGCG exhibited a dose-dependent radical scavenging activity between 10 and $100 \mu \mathrm{M}$. As a common antioxidant, ascorbic acid at the same concentrations was used as a positive control (Figure 2(a)) [46]. Apart from its antioxidant effects, EGCG may also possess other beneficial functions. Therefore, the effect of EGCG on the accumulation of SA $\beta$-gal was tested in 3 different experimental setups displayed 


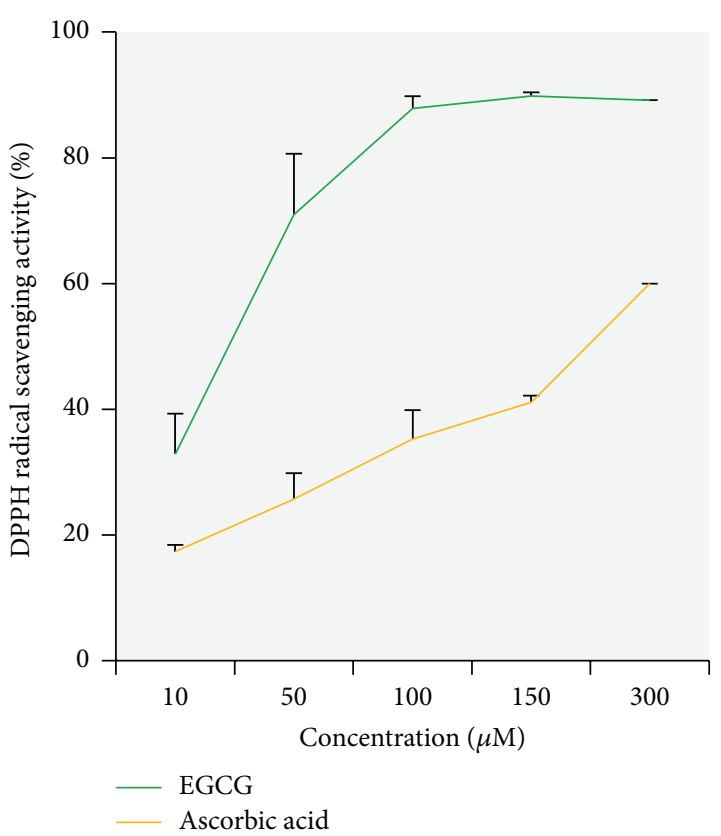

(a)

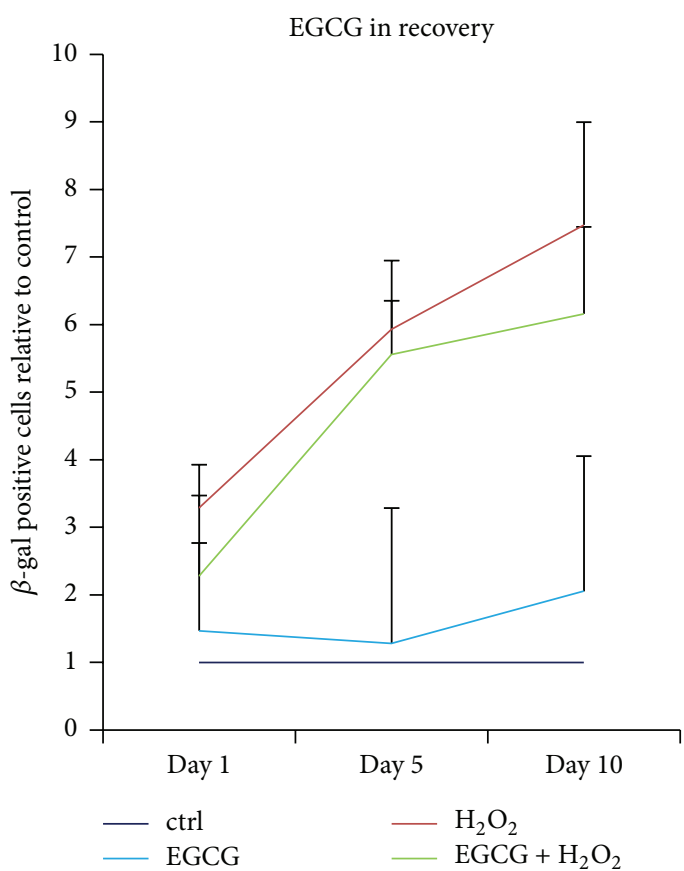

(c)

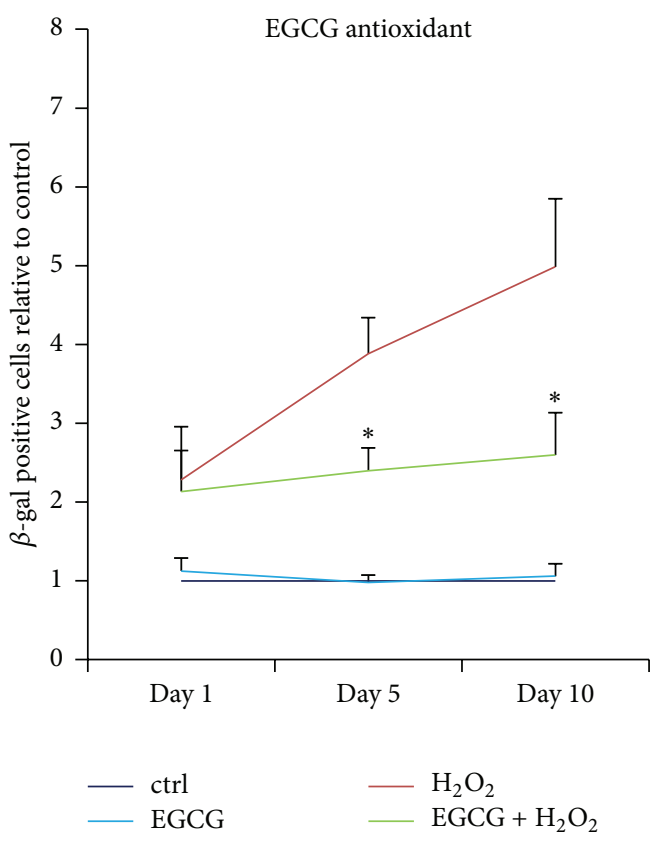

(b)

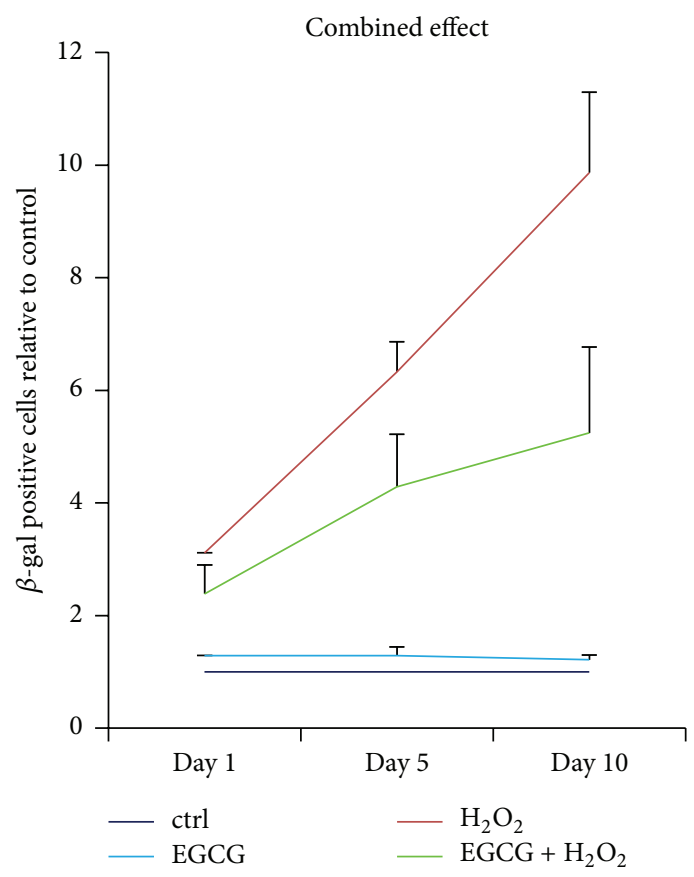

(d)

FIGURE 2: As an antioxidant, EGCG inhibited senescence-associated $\beta$-galactosidase accumulation. (a) EGCG exhibited increasing 2,2diphenyl-1-picrylhydrazyl (DPPH) radical scavenging activity between 10 and $100 \mu \mathrm{M}$, which confirmed its antioxidant properties. Ascorbic acid in the same concentration was used as positive control $(n=3)$. ((b)-(d)) Oxidative stress was induced with $50 \mu \mathrm{M} \mathrm{H}_{2} \mathrm{O}_{2}$ for 2 hours and cellular senescence was measured during the following 10 days. $10 \mu \mathrm{M}$ EGCG inhibited SA $\beta$-gal accumulation when added to the oxidative stress phase, when its antioxidant activity was confirmed $(n=5)$. (c) $10 \mu \mathrm{M}$ EGCG added to the recovery phase did not influence SA $\beta$-gal accumulation compared to the $\mathrm{H}_{2} \mathrm{O}_{2}$-only group $(n=5)$. (d) EGCG combined in both phases $(5+5 \mu \mathrm{M})$ did not significantly inhibit SA $\beta$-gal accumulation, although a trend is visible $(n=5)$. Asterisks indicate statistical significance at $p<0.05$ (ANOVA, Tukey post hoc). 
in Table 2, namely, (1) antioxidant activity by adding EGCG in the stress phase, (2) activity on poststress signaling by adding EGCG in the recovery phase, and (3) potential combined effect by adding EGCG in both phases.

The percentage of SA $\beta$-gal positive cells was evaluated on days 1, 5, and 10 after stress. EGCG significantly inhibited the accumulation of SA $\beta$-gal on days 5 and 10 when added during the stress phase, indicating that an antioxidant mechanism is involved (Figure 2(b)). EGCG did not influence the rate of SA $\beta$-gal accumulation during the recovery phase, suggesting that the interaction of EGCG with poststress signaling is less relevant (Figure 2(c)). The presence of EGCG in both phases did not provide significant protection against oxidative stress, which is most likely caused by insufficient ROS neutralization, as lower concentrations of EGCG (5 $\mu \mathrm{M})$ were used in the stress phase of this setup. However, an apparent trend towards statistical significance was detectable (Figure 2(d)).

3.3. EGCG Did Not Protect IVD Cells from Loss of Proliferative Capacity in Sublethal Oxidative Stress. The effects of EGCG on proliferation and expression of the senescence markers p53 and p21 were also tested in each experimental setup: (1) EGCG as an antioxidant, (2) EGCG in recovery, and (3) combined effects. In order to compare the proliferative capacity of $\mathrm{H}_{2} \mathrm{O}_{2}$-treated and $\mathrm{H}_{2} \mathrm{O}_{2}+$ EGCG-treated cell populations, the number of viable cells on day 10 of recovery period was determined in each treatment group. Untreated and EGCG-treated cells proliferated, but all stress groups showed significantly lower cell numbers, regardless of the presence of EGCG (Figures 3(a)-3(c)). On day 10 after stress, p53 was slightly phosphorylated in all stress groups. Expression of p21 was induced by $\mathrm{H}_{2} \mathrm{O}_{2}$ but also not affected by the presence of EGCG, hence indicating that exogenous ROS were not entirely neutralized by $10 \mu \mathrm{M}$ EGCG (Figures $3(\mathrm{~d})-3(\mathrm{f}))$.

As both nonsenescent and senescent cells are metabolically active, detected metabolic activity on day 10 corresponds to the number of cells in each treatment group: stress groups showed significantly lower metabolic activity than untreated controls. No significant difference between the $\mathrm{H}_{2} \mathrm{O}_{2}$ and $\mathrm{H}_{2} \mathrm{O}_{2}+$ EGCG treatment groups was detected in either experimental setup, confirming that EGCG did not protect IVD cells from loss of proliferative capacity (Figures $3(\mathrm{~g})-$ $3(\mathrm{i})$ ). Metabolic activity of cells on day 10 is displayed relative to the control group (100\%).

\subsection{EGCG Protected IVD Cells from Lethal Oxidative Stress} via Inhibition of Mitochondrial Membrane Depolarization. Based on the sensitivity study, $100 \mu \mathrm{M}$ and $200 \mu \mathrm{M} \mathrm{H}_{2} \mathrm{O}_{2}$ applied for 24 hours were identified to trigger significant cell death (Supplementary Figure 1). As such ROS doses may induce excessive mitochondria membrane depolarization and unrepairable damage, the general prosurvival effect of EGCG can be tested.

Extensive oxidative stress $\left(100 \mu \mathrm{M} \mathrm{H}_{2} \mathrm{O}_{2}\right)$ significantly decreased the metabolic activity of IVD cells (51.49 \pm $5.64 \%)$, compared with the control group (100\%), while the addition of EGCG reversed this effect $(80.58 \pm 4.31 \%)$ (Figure 4(a)). More specifically, PI/A staining confirmed significantly higher number of living cells in the $\mathrm{H}_{2} \mathrm{O}_{2}+$ EGCG treatment group $(52.91 \pm 8.02 \%)$ compared to the $\mathrm{H}_{2} \mathrm{O}_{2}$-only group (28.31 $\pm 5.83 \%$ ) (Figure $4(\mathrm{~b})$ ).

During lethal oxidative stress, mitochondria lose their transmembrane potential, which leads to the release of mitochondrial ROS and serves as a proapoptotic signal. EGCG may possibly interact with ROS on the mitochondrial membrane and prevent further ROS leakage. To test this hypothesis, the JC-1 dye, which forms red aggregates in intact mitochondria, was used. $\mathrm{H}_{2} \mathrm{O}_{2}$ in a concentration of $100 \mu \mathrm{M}$ (Figure 5(a)) and $200 \mu \mathrm{M}$ (Figure 5(b)) caused extensive mitochondrial membrane depolarization, while the addition of EGCG prevented this effect. The red/green fluorescence ratio of the untreated $(10.19 \pm 4.54)$ and the EGCG-treated $(8.15 \pm 3.29)$ cells was significantly higher than the ratio of both $\mathrm{H}_{2} \mathrm{O}_{2}$ treatment groups $(100 \mu \mathrm{M}$ : $1.85 \pm$ $0.96,200 \mu \mathrm{M}: 0.09 \pm 0.07$ ). Addition of EGCG significantly increased the ratio in $\mathrm{H}_{2} \mathrm{O}_{2}$ treatment groups to $6.05 \pm 1.14$ $(100 \mu \mathrm{M})$ and $0.63 \pm 0.2(200 \mu \mathrm{M})$ (Figure 5(d)). Membrane blebbing and nuclear shrinkage were detected in the $\mathrm{H}_{2} \mathrm{O}_{2}+$ EGCG treatment group, confirming that the cells were not completely protected from deleterious ROS and cell death was possibly only delayed (Figure 5(c)).

\subsection{EGCG Increased Survival of IVD Cells in Lethal Oxidative} Stress via PI3K/Protein Kinase B (Akt) Activation. To further explore the mechanism underlying the action of EGCG, the activity of the prosurvival PI3K/Akt pathway was studied. As shown by immunoblotting, EGCG activated Akt under oxidative stress conditions (Figure 6(a)). The biological relevance of this finding was tested using the PI3K/Akt-specific inhibitor LY294002 (LY). Depending on the type of stimulus, Akt can activate various downstream signaling pathways inducing proliferation, glucose metabolism, or survival. Akt activator insulin, which stimulates cell proliferation, was used as positive control to confirm the activity and specificity of LY. As expected, insulin modestly increased the proliferation of IVD cells ( $117.79 \pm 2.91 \%$ versus $100 \%$ in control), whereas the addition of LY abolished this effect $(108.16 \pm 2.86 \%)$, hence confirming the activity of LY for further PI3K/Akt pathway tests (Supplementary Figure 1).

PI3K/Akt inhibition with LY did not significantly alter the prosurvival effect of EGCG at 24 hours, as measured by MTT assay (Figure 6(b)). However, at longer time points (48 hours), the difference in the metabolic activity between the $\mathrm{H}_{2} \mathrm{O}_{2}+$ EGCG $(80.01 \pm 8.93 \%)$ and the $\mathrm{H}_{2} \mathrm{O}_{2}+$ EGCG + LY (34.81 $\pm 4.69 \%)$ treatment group became significant (Figure 6(c)), indicating that EGCG-based activation of the PI3K/Akt pathway plays indeed an important role in the survival of IVD cells under the oxidative stress.

\section{Discussion}

A stress-related decrease in the number of viable cells and phenotypic changes of living cells are two major events in the process of IVD degeneration that warrant therapeutic 


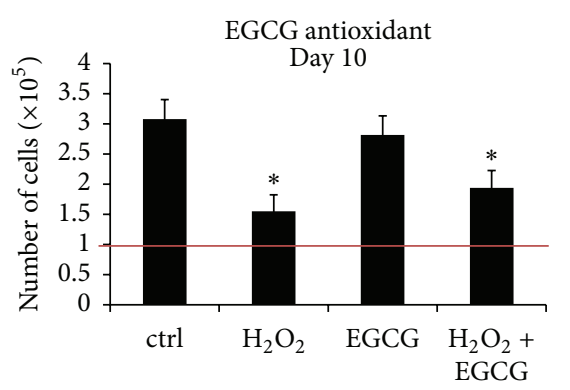

(a)

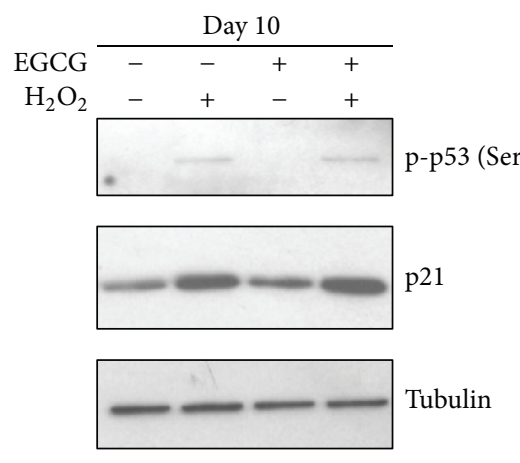

(d)

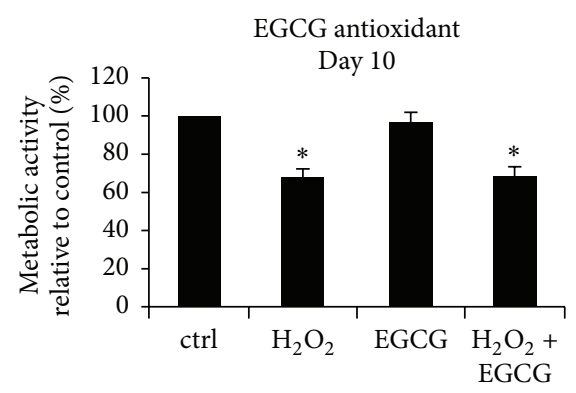

(g)

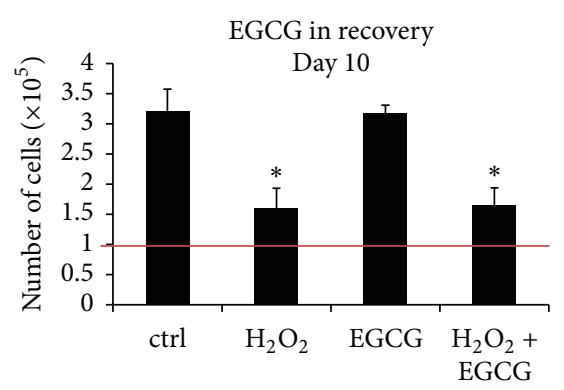

(b)

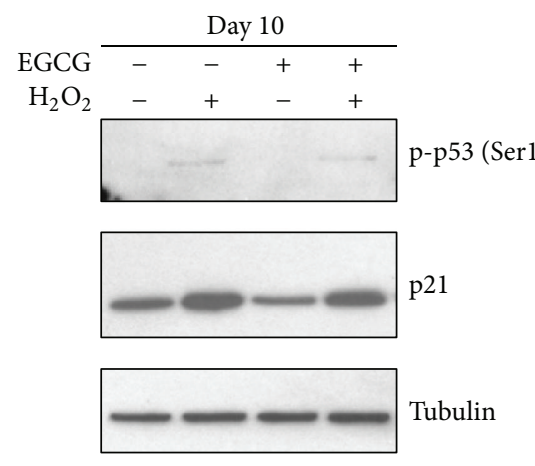

(e)

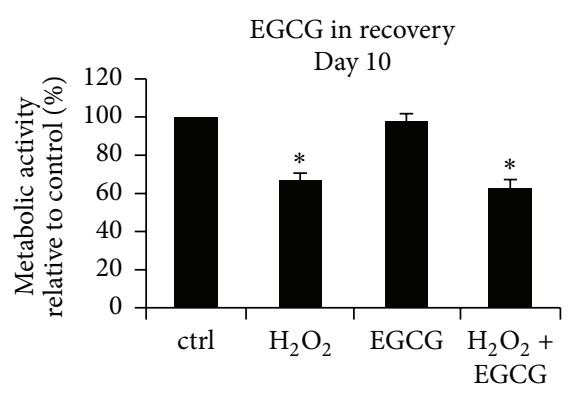

(h)

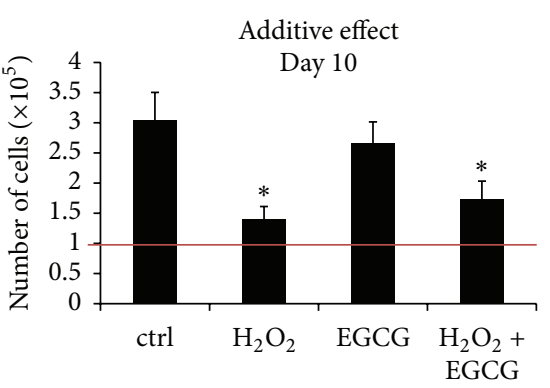

(c)

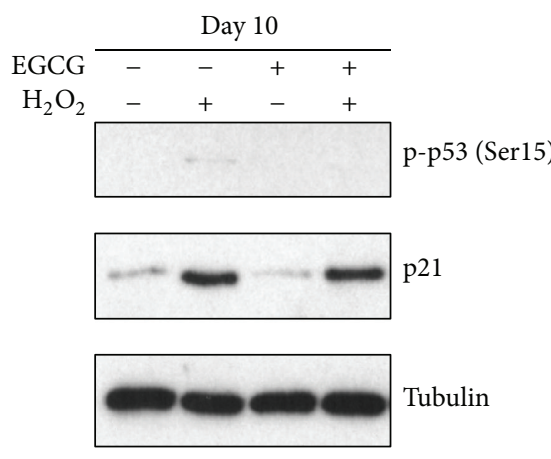

(f)

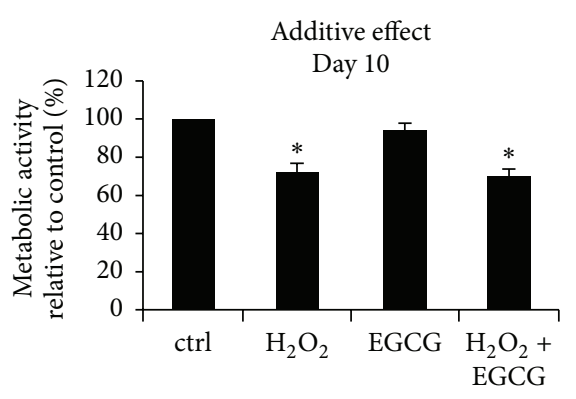

(i)

FIGURE 3: EGCG did not influence reactive oxygen species-induced loss of proliferative capacity. Senescence of IVD cells was induced with $50 \mu \mathrm{M} \mathrm{H}_{2} \mathrm{O}_{2}$ for 2 hours and proliferative capacity was evaluated on day 10 after stress. ((a)-(c)) Over a period of 10 days, the $\mathrm{H}_{2} \mathrm{O}_{2}$-treated cells proliferated significantly less than the cells in control groups. The number of cells in the $\mathrm{H}_{2} \mathrm{O}_{2}$ and $\mathrm{H}_{2} \mathrm{O}_{2}+10 \mu \mathrm{M}$ EGCG treatment groups did not significantly differ in either experimental setup $(n=5)$. ((d)-(f)) The activity of p53 and the expression of p21 were not significantly affected by EGCG in either experimental setup $(n=5)$. ( (g)-(i)) Metabolic activity in the $\mathrm{H}_{2} \mathrm{O}_{2}$ and the $\mathrm{H}_{2} \mathrm{O}_{2}+$ EGCG treatment groups did not significantly differ, indicating reduced proliferative capacity in all stress groups $(n=5)$. Asterisks indicate statistical significance at $p<0.05$ versus control group (ANOVA, Tukey post hoc).

targeting [32]. Oxidative stress-induced senescence and cell death in vitro can represent mechanisms involved in human disc aging in vivo $[20,21,28]$. We hypothesized that the natural polyphenol EGCG can inhibit oxidative stress-induced senescence and/or cell death of IVD cells and we investigated which mechanisms may be involved in its action.

In vitro as well as in vivo, EGCG can directly interact with ROS or operate in an indirect manner by inhibiting ROS generating enzymes or by chelating potentially prooxidant metal ions [47]. Nevertheless, antioxidant activity is not the only biological effect of EGCG. In fact, many of its healthbeneficial functions are independent of redox reactions. Depending on the cell type, EGCG can interact with proteins and phospholipids in the plasma membrane, regulate signal transduction and gene expression and DNA methylation, and modulate mitochondrial function and autophagy [48].

Results of the radical scavenging assay confirmed the previously reported antioxidant activity of $10 \mu \mathrm{M}$ EGCG, which can neutralize $32.89 \pm 6.39 \%$ of $250 \mu \mathrm{M} \mathrm{DPPH}$ radicals. Although higher concentrations of EGCG exhibited better ROS trapping, they were not used in this study to avoid possible unfavorable interactions with cell culture media components. Dose-dependent oxidation of polyphenols and subsequent ROS generation was reported as a common artifact of in vitro cell culture $[49,50]$. The thus induced toxicity has no significance in vivo, because of the presence of plasma antioxidants, but can interfere with research hypotheses via increasing unspecific stress in cell culture. From this point of 


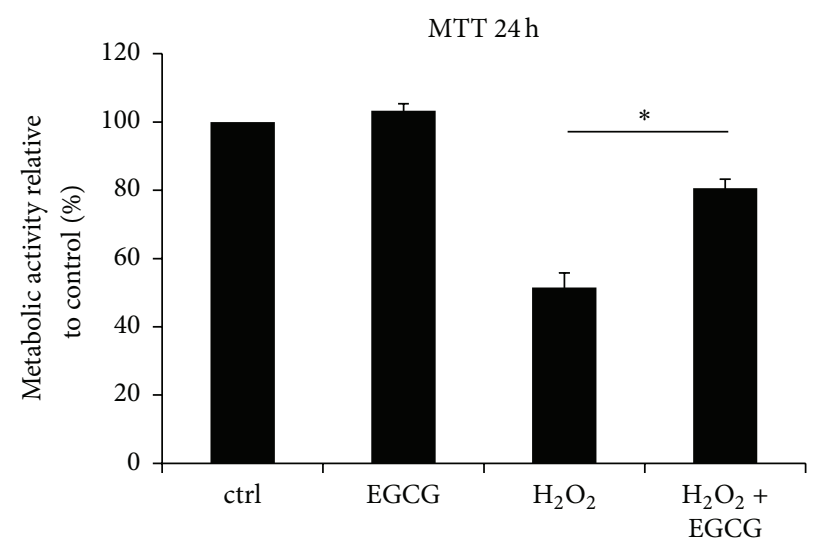

(a)

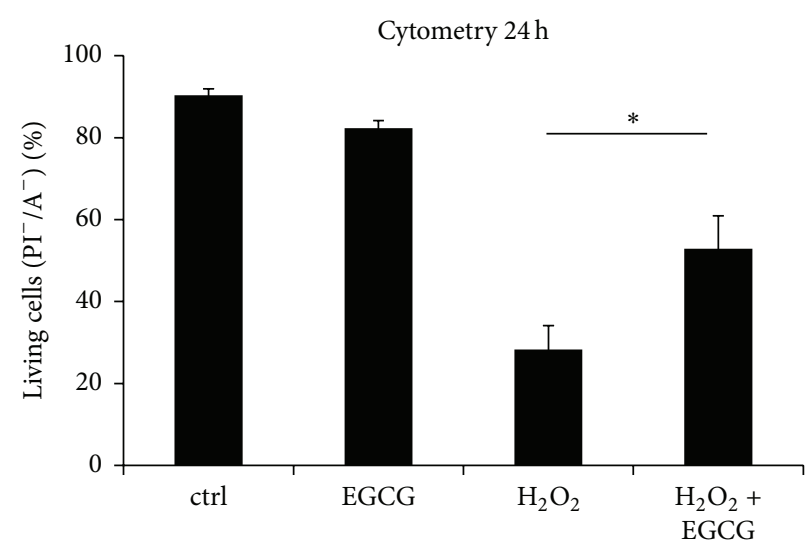

(b)
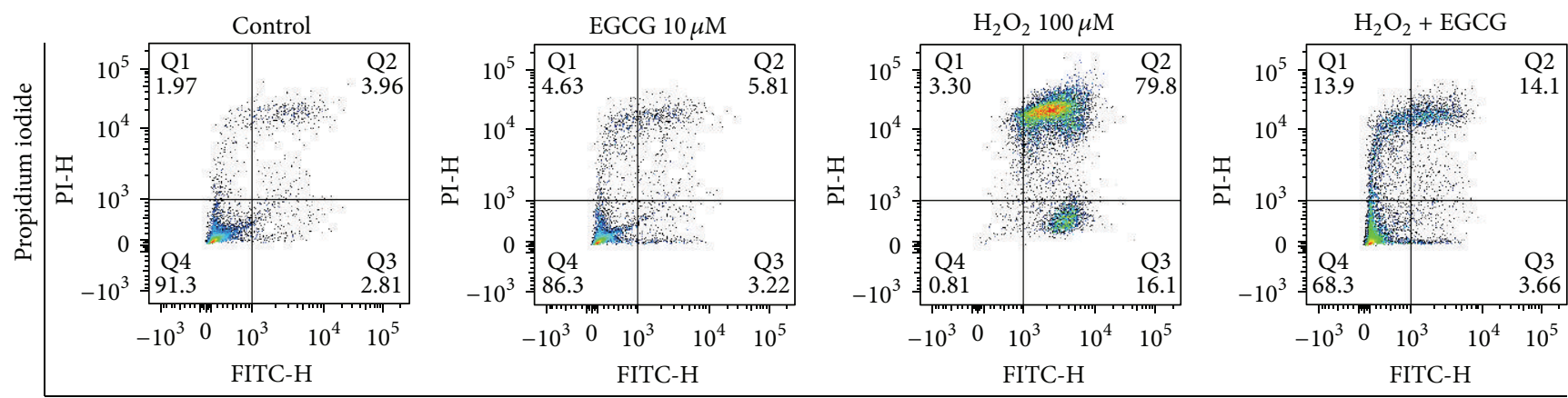

FITC-Annexin V

(c)

FIGURE 4: EGCG significantly inhibited reactive oxygen species-induced cell death. Cell death was induced by lethal concentration of $\mathrm{H}_{2} \mathrm{O}_{2}$ $(100 \mu \mathrm{M})$ applied for 24 hours. (a) $10 \mu \mathrm{M}$ EGCG significantly reversed the detrimental effects of $\mathrm{H}_{2} \mathrm{O}_{2}$ on metabolic activity, measured by MTT assay $(n=10)$. (b) $10 \mu \mathrm{M}$ EGCG also significantly increased cell viability in oxidative stress, as measured by Propidium Iodide/Annexin staining $(n=5)$. (c) Visualization of representative Propidium Iodide/Annexin V staining measured by flow cytometry. Asterisks indicate statistical significance at $p<0.05$ (Student's $t$-test).

view, $10 \mu \mathrm{M}$ EGCG was considered active, yet experimentally safe.

We developed an in vitro model system of premature senescence of IVD cells, induced by sublethal oxidative stress. Due to the vastly heterogeneous nature of the senescence phenotype, the use of various markers is required to precisely identify senescence in a given cell population [14]. The expression of certain markers, such as p21, can also increase during in vitro cell culture as an artifact (Supplementary Figure 1). Senescent cells commonly undergo cell cycle arrest, start expressing SA $\beta$-gal, exhibit a senescence-associated secretory phenotype (SASP), and activate p53-p21 and/or p16-RB pathways $[15,27]$. The morphology of senescent cells can differ from their young counterparts: cells become bigger, with prominent nucleoli and numerous cytoplasmic vacuoles [51]. Sublethal doses of the widely used oxidative stress inducer $\mathrm{H}_{2} \mathrm{O}_{2}$ inhibited proliferation and activated the p53p21 pathway and SA $\beta$-gal accumulation in IVD cells, proving the suitability of the system to test potential antisenescence compounds.

EGCG did not influence the progress of senescence when applied during the recovery phase, suggesting no interaction with poststress signaling. During recovery after oxidative stress, cells can undergo several changes, one of which can be the activation of gene expression towards the senescence-associated secretory phenotype (SASP). The SASP is mediated, for example, by the transcription factor nuclear factor $\kappa \mathrm{B}(\mathrm{NF}-\kappa \mathrm{B})$ and many other redox-sensitive transcription factors, which can induce the expression of proinflammatory cytokines, proteases, and catabolic enzymes $[11,15,37]$. We have shown before that EGCG inhibited IL-1 $\beta$ activated inflammatory responses in the IVD [38], implying that EGCG may act via similar mechanisms also in the ROSactivated SASP. However, sublethal oxidative stress in our settings did not increase the expression of inflammatory markers (IL-6, IL-8) and catabolic enzymes (MMP1, MMP3, and MMP13). Therefore, the effect of EGCG on SASP could not be evaluated (Supplementary Figure 1). Previously, stressinduced SASP was activated in IVD cells under different culture conditions [27]; in our setup either longer time point or higher ROS concentration may potentially be required.

As an antioxidant, $10 \mu \mathrm{M}$ EGCG inhibited accumulation of SA $\beta$-gal but did not protect IVD cells from loss of proliferative capacity, suggesting that the exogenous radicals were not entirely neutralized. The increase in SA $\beta$-gal expression/activity results from the need to compensate for 

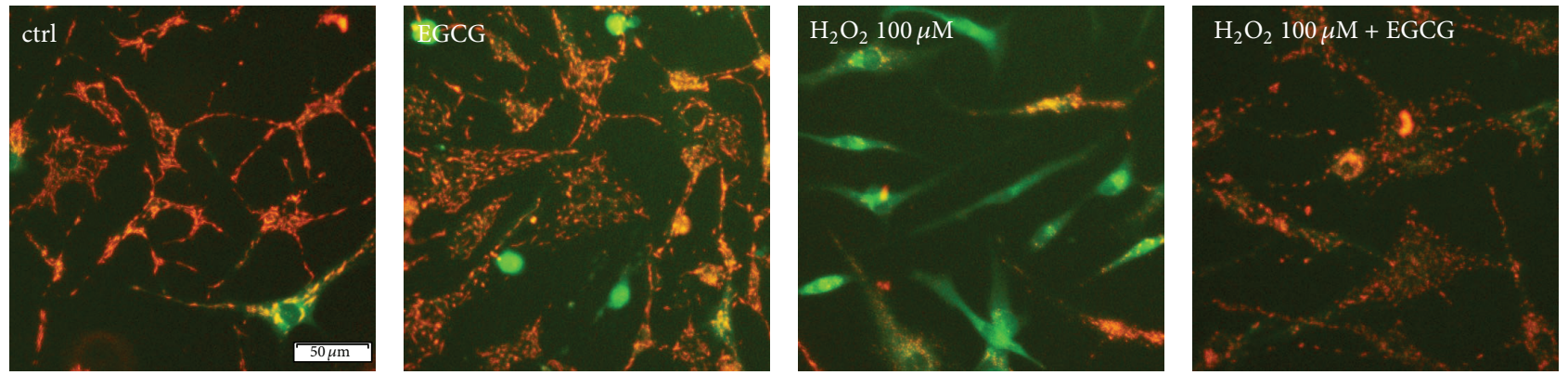

(a)
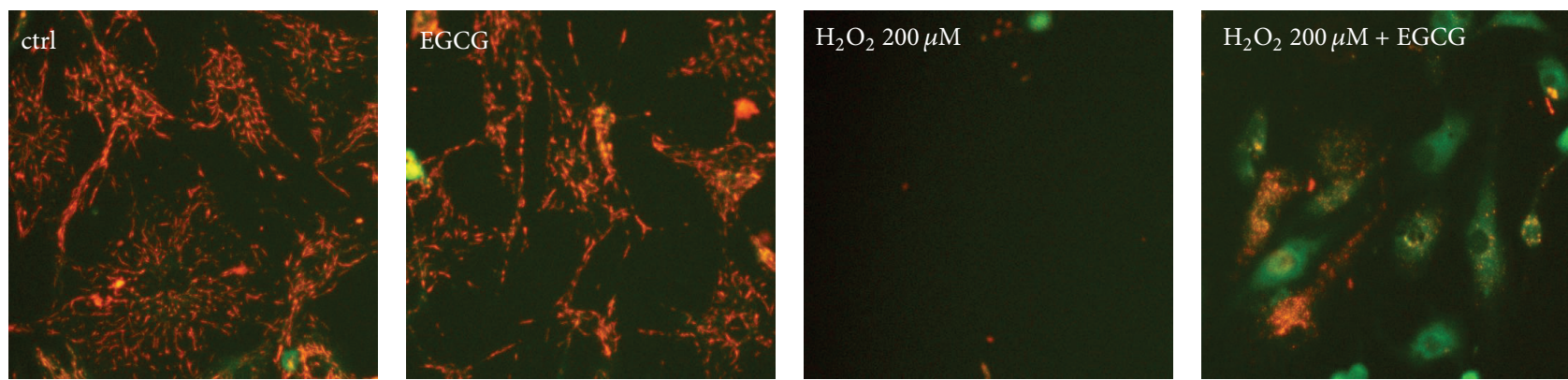

(b)
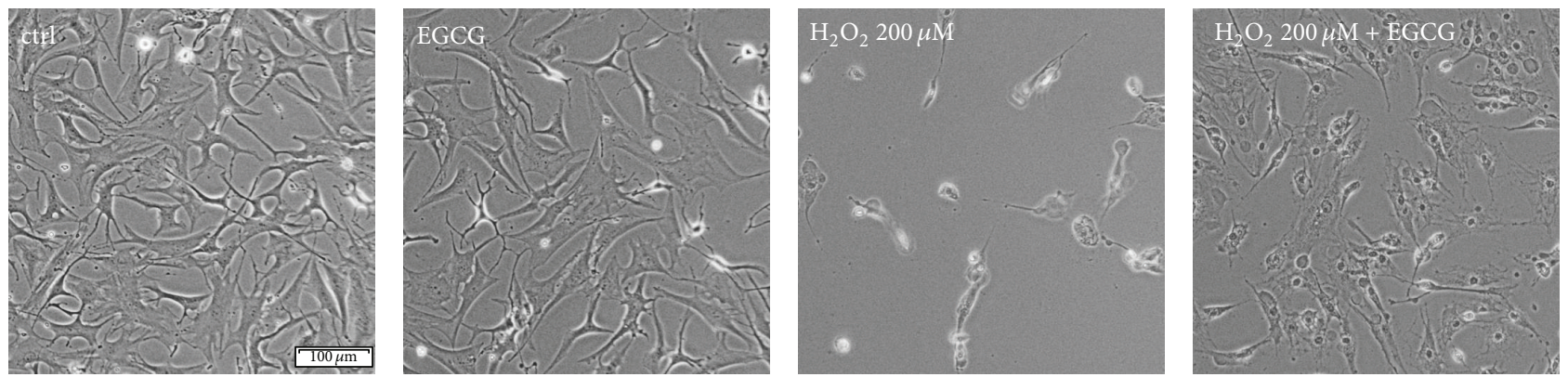

(c)

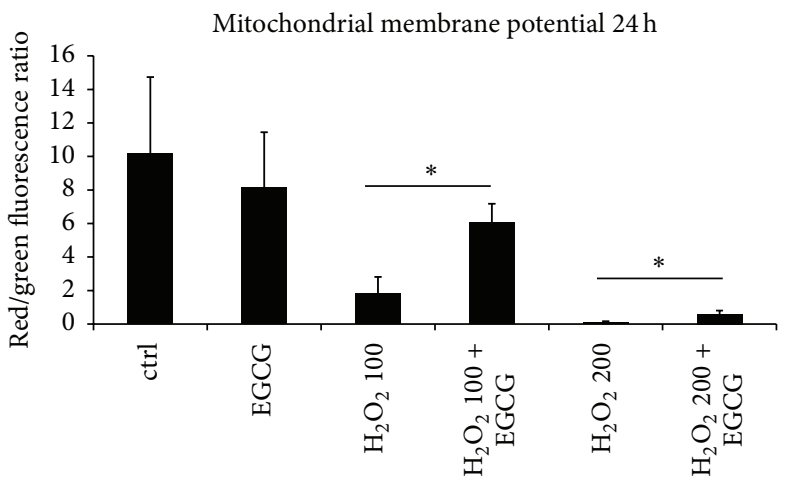

(d)

FIGURE 5: EGCG inhibited the loss of mitochondrial membrane potential. Cell death was activated by lethal concentrations of $\mathrm{H}_{2} \mathrm{O}_{2}(100 \mu \mathrm{M}$, $200 \mu \mathrm{M}$ ) applied for 24 hours. (a) $10 \mu \mathrm{M}$ EGCG significantly inhibited mitochondrial membrane depolarization induced with $100 \mu \mathrm{M}$ $\mathrm{H}_{2} \mathrm{O}_{2}(n=10)$. (b) $10 \mu \mathrm{M}$ EGCG significantly inhibited mitochondrial membrane depolarization induced with $200 \mu \mathrm{M} \mathrm{H} \mathrm{O}_{2}(n=10)$. (c) Cellular morphology of the $\mathrm{H}_{2} \mathrm{O}_{2}+$ EGCG treatment group was different from the control group: signs of membrane blebbing and nuclear condensation indicated that cell death was not completely inhibited $(n=5)$. (d) Ratio of red/green fluorescence showing the loss of mitochondrial membrane potential in the $\mathrm{H}_{2} \mathrm{O}_{2}$ treatment groups. Asterisks indicate statistical significance at $p<0.05$ (ANOVA, Tukey post hoc). 


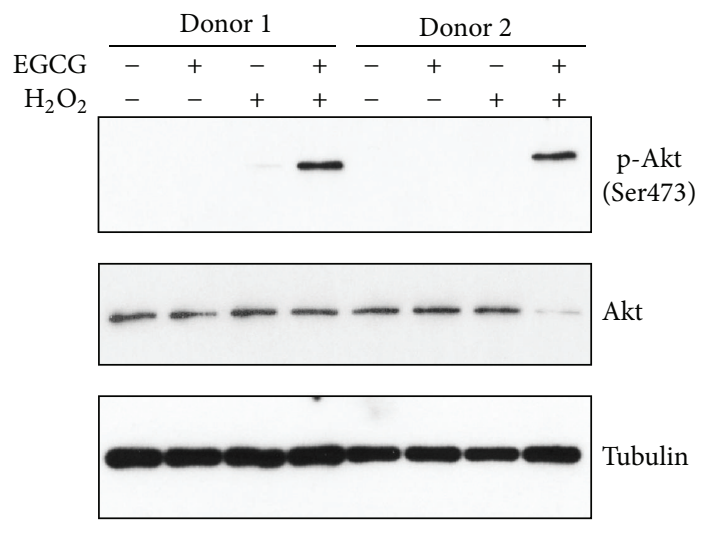

(a)

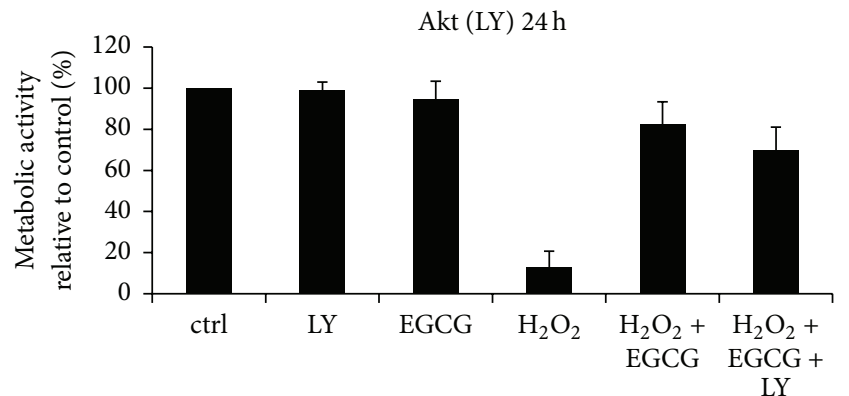

(b)

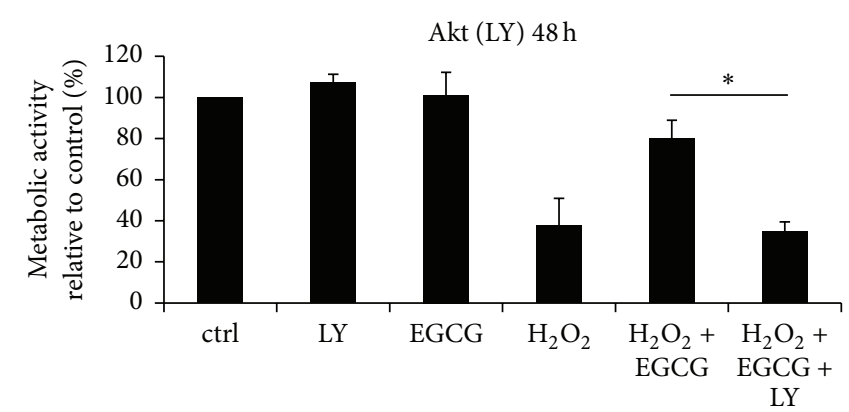

(c)

FIGURE 6: PI3K/Akt is important for the protective function of EGCG under the lethal oxidative stress. Cell death was activated by $200 \mu \mathrm{M}$ $\mathrm{H}_{2} \mathrm{O}_{2}$. (a) After 15 minutes of cotreatment, $10 \mu \mathrm{M}$ EGCG activated PI3K/Akt $(n=5)$ ). (b) After 24 hours, no significant difference in metabolic activity between the $\mathrm{H}_{2} \mathrm{O}_{2}+$ EGCG and the $\mathrm{H}_{2} \mathrm{O}_{2}+$ EGCG + LY groups was detected $(n=5)$. (c) After 48 hours, LY completely abolished the protective effects of EGCG, underlying the importance of the PI3K/Akt pathway in the survival of IVD cells $(n=5)$. Asterisks indicate statistical significance at $p<0.05$ (ANOVA, Tukey post hoc).

the accumulation of damaged macromolecules and organelles in lysosomes. As the expression of SA $\beta$-gal is not required for senescence, we hypothesize that EGCG in the antioxidant setup can ameliorate the increase in lysosome dysfunction, rather than inhibiting a complex senescence phenotype. In accordance with that, EGCG has been shown to promote macroautophagy and lysosome recycling of accumulated intracellular materials [52, 53]. Nevertheless, the role of EGCG in enhancing cellular waste-disposal mechanisms is still controversial and presumably cell-type specific.

Since EGCG inhibited SA $\beta$-gal accumulation in the antioxidant setup and not in the recovery setup, one could expect similar responses when combining EGCG in both stress and recovery phase. However, in the third setup, SA $\beta$-gal assay showed only a trend towards the statistical significance, possibly because a lower EGCG concentration was applied in the stress phase, in order to avoid potential toxic effects mentioned above [54].

As p16 is another important senescence marker, its expression was initially tested in IVD cells treated with EGCG in the antioxidant settings, on day $10(n=4)$. Because of the fact that p16 expression in $\mathrm{H}_{2} \mathrm{O}_{2}$ treatment groups was detected only in 1 out of 4 donors, the experiments on p16 expression were not continued (Supplementary Figure 2). In fact, the relative contributions of the p53-p21 and p16-RB pathways to the senescence growth arrest may vary, depending on the type and level of stress [55]. Moreover, in different cell types, the transition of temporal to stable cell cycle arrest can involve either an activation of p21 or p16 or an activation of both [55]. Human IVD cells are generally slowly proliferating and responding cell type in which ROS can possibly induce p16 with delayed kinetics. p16, if activated, subsequently provides a second barrier to stop cell proliferation and plays a role in maintaining senescence, rather than in its initiation, as suggested before [56,57], which may explain its low expression in our study.

To test whether EGCG can influence the expression of p16, SAOS-2 cells, with constitutive expression of p16, were treated with $10 \mu \mathrm{M}$ EGCG for 24 hours. This experiment showed no influence of EGCG on the expression of p16 in SAOS-2 (Supplementary Figure 2).

Lethal oxidative stress causes unrepairable damage on mitochondrial membranes, leading to extensive ROS leakage and quick activation of death signals [58] (Supplementary Figure 3). Two independent viability assays revealed that EGCG can significantly increase survival of IVD cells in lethal oxidative stress. As a primary target of oxidative stress, 
mitochondria quickly lose their membrane integrity. We demonstrated that EGCG can delay the onset of mitochondrial membrane depolarization, hence protecting mitochondria from ROS leakage. Similar antioxidant effects of EGCG were previously described, for example, in the mice liver injury in vivo model [59] or in rat retinal primary cells in vitro [60].

As an exogenous oxidizing agent, $\mathrm{H}_{2} \mathrm{O}_{2}$ produces hydroxyl radicals, which can efficiently react with all cellular components. On the other hand, damaged mitochondria generate mainly superoxide, followed by lower amounts of hydrogen peroxide and hydroxyl radicals $[61,62]$. Therefore, EGCG can affect mitochondrial ROS leakage by being a good superoxide anion radical scavenger [62], but it may neutralize other ROS species less efficiently (Supplementary Figure 3). As previously reported, EGCG can also activate superoxide dismutase expression, another mechanism to counteract exclusively superoxide anion radicals and to protect mitochondria $[63,64]$.

Interestingly, EGCG activated PI3K/Akt under lethal oxidative stress, an ability that was important for IVD cell survival. We suggest that the reason why EGCG alone did not activate PI3K/Akt pathway can be an absence of the stress signal $\left(\mathrm{H}_{2} \mathrm{O}_{2}\right)$. In nonstressed cells, the activity of prosurvival pathways (such as PI3K/Akt) is negatively regulated by their inhibitors (such as PTEN). In stressed cells, the activity of intracellular kinase inhibitors can be reduced [65] in order to facilitate activation of the prosurvival kinases. However, the prosurvival kinases can fully function only upon external activation [66]. Interestingly, it has been shown that EGCG interacts with various membrane receptors $[48,67]$. We therefore hypothesize that EGCG-mediated interaction upstream of Akt, in combination with stressmediated reduction in the activity of intracellular kinase inhibitors, can lead to complete PI3K/Akt activation and prosurvival effects in $\mathrm{H}_{2} \mathrm{O}_{2}$-treated cells.

Previously, Akt gene expression has been correlated with increased disc cell proliferation in vitro [68] and lumbar disc herniation in vivo [69]. More importantly, active PI3K/Akt signaling enhanced prosurvival capacity of disc cells in vitro [70] and antagonized disc degeneration in vivo [71]. The $\mathrm{PI} 3 \mathrm{~K} / \mathrm{Akt}$ pathway can therefore represent another attractive therapeutic goal in disc degeneration, which can be targeted by EGCG.

In this study, 2D cell culture was employed to ensure applicability of cell analysis assays. Adherent in vitro system, in contrast to $3 \mathrm{D}$, reduced cell loss during analyses, which is particularly important for stress experiments. The $2 \mathrm{D}$ system also allowed quick and precise staining of organelles in living cells. While results are very clear, it remains open whether cells react similarly in their natural $3 \mathrm{D}$ environment. This study is furthermore limited by the interdonor variability of disc tissue biopsies, originating from differences in age and degeneration grades [72]. Nevertheless, the use of primary cells during first three passages represents a system more close to human tissue than a stabilized cell line. The interdonor variability issue can be corrected by displaying results relative to a control group, instead of using absolute numbers.
The main third limitation is that the effect of EGCG during the recovery phase of senescence was tested in complete media, which could possibly influence the activity of EGCG.

\section{Conclusions}

This study showed that EGCG can counteract oxidative stress-induced changes of IVD cells in vitro via protection of the mitochondrial membrane from depolarization. In oxidative stress, EGCG also activated PI3K/Akt as an important prosurvival mechanism of IVD cells. As this study did not provide direct evidence whether and how the EGCG activated Akt and mitochondria protection are linked, investigation of this coupling in IVD cells will be an objective of future research.

Together with previously reported anti-inflammatory, anticatabolic, and analgesic effects of EGCG, our findings can be further used for the development of novel therapies targeting consequences of oxidative stress and neovascularization in degenerative disc disease.

$\begin{array}{ll}\text { Abbreviations } \\ \text { A: } & \text { Annexin V-FITC } \\ \text { AF: } & \text { Annulus fibrosus } \\ \text { Akt: } & \text { Protein kinase B } \\ \text { EGCG: } & \text { Epigallocatechin 3-gallate } \\ \text { IL: } & \text { Interleukin } \\ \text { IVD: } & \text { Intervertebral disc } \\ \text { JC-1: } & 5,5^{\prime}, 6,6^{\prime} \text {-Tetrachloro- } 1,1^{\prime}, 3,3^{\prime} \text { - } \\ & \text { tetraethylbenzimidazolcarbocyanine } \\ & \text { iodide } \\ \text { LY: } & \text { LY294002 } \\ \text { MMP: } & \text { Matrix metalloproteinase } \\ \text { MTT: } & 3 \text { - }[4,5 \text {-Dimethylthiazol-2-yl]-2,5-diphenyl } \\ & \text { tetrazolium bromide } \\ \text { NF- } \kappa \text { B: } & \text { Nuclear factor kappa-light-chain-enhancer } \\ & \text { of activated B cells } \\ \text { NP: } & \text { Nucleus pulposus } \\ \text { PI: } & \text { Propidium Iodide } \\ \text { ROS: } & \text { Reactive oxygen species } \\ \text { SA } \beta \text {-gal: } & \text { Senescence-associated } \beta \text {-galactosidase } \\ \text { SASP: } & \text { Senescence-activated secretory phenotype. }\end{array}$

\section{Competing Interests}

The authors have no competing interests.

\section{Authors' Contributions}

Olga Krupkova carried out sublethal stress experiments, participated in lethal stress experiments, contributed to study design, and drafted the paper. Junichi Handa participated in lethal stress experiments and performed pathway analysis and statistical analysis. Marian Hlavna performed gene expression experiments and statistical analysis. Juergen Klasen participated in study design and provided clinical 
samples and medical scientific input. Caroline Ospelt conceived funding, participated in study design, and provided scientific input. Stephen John Ferguson conceived funding, helped with study design and coordination, and helped draft the paper. Karin Wuertz-Kozak conceived funding, designed and coordinated the study, and helped draft the paper. All authors approved a final version of the paper. Olga Krupkova and Junichi Handa contributed equally to this work.

\section{Acknowledgments}

The authors would like to thank the Herzog-Egli Foundation and the Mäxi Foundation for financial support, Sonia Rossi for preliminary $\mathrm{H}_{2} \mathrm{O}_{2}$ tests, and Helen Greutert and ETH FACS core facility for technical support.

\section{References}

[1] B. A. Walter, O. M. Torre, D. Laudier, T. P. Naidich, A. C. Hecht, and J. C. Iatridis, "Form and function of the intervertebral disc in health and disease: a morphological and stain comparison study," Journal of Anatomy, vol. 227, no. 6, pp. 707-716, 2015.

[2] K. Wuertz and L. Haglund, "Inflammatory mediators in intervertebral disk degeneration and discogenic pain," Global Spine Journal, vol. 3, no. 3, pp. 175-184, 2013.

[3] S. S. Sivan, E. Wachtel, and P. Roughley, "Structure, function, aging and turnover of aggrecan in the intervertebral disc," Biochimica et Biophysica Acta (BBA)_General Subjects, vol. 1840, no. 10, pp. 3181-3189, 2014.

[4] G. Fontana, E. See, and A. Pandit, "Current trends in biologics delivery to restore intervertebral disc anabolism," Advanced Drug Delivery Reviews, vol. 84, pp. 146-158, 2015.

[5] W. Wu, X. L. Zhang, X. Q. Hu et al., "Lactate down-regulates matrix systhesis and promotes apoptosis and autophagy in rat nucleus pulposus cells," Journal of Orthopaedic Research, vol. 32, no. 2, pp. 253-261, 2014.

[6] L. Poveda, M. Hottiger, N. Boos, and K. Wuertz, "Peroxynitrite induces gene expression in intervertebral disc cells," Spine, vol. 34, no. 11, pp. 1127-1133, 2009.

[7] E. D. Schleicher, E. Wagner, and A. G. Nerlich, "Increased accumulation of the glycoxidation product Nepsilon(carboxymethyl)lysine in human tissues in diabetes and aging," The Journal of Clinical Investigation, vol. 99, no. 3, pp. 457-468, 1997.

[8] S. S. Sivan, E. Tsitron, E. Wachtel et al., "Age-related accumulation of pentosidine in aggrecan and collagen from normal and degenerate human intervertebral discs," Biochemical Journal, vol. 399, no. 1, pp. 29-35, 2006.

[9] A. G. Nerlich, B. E. Bachmeier, E. Schleicher, H. Rohrbach, G. Paesold, and N. Boos, "Immunomorphological analysis of RAGE receptor expression and NF- $\kappa \mathrm{B}$ activation in tissue samples from normal and degenerated intervertebral discs of various ages," Annals of the New York Academy of Sciences, vol. 1096, pp. 239-248, 2007.

[10] K.-W. Kim, H.-N. Chung, K.-Y. Ha, J.-S. Lee, and Y.-Y. Kim, "Senescence mechanisms of nucleus pulposus chondrocytes in human intervertebral discs," Spine Journal, vol. 9, no. 8, pp. 658666, 2009.

[11] H. Y. Chung, B. Sung, K. J. Jung, Y. Zou, and B. P. Yu, "The molecular inflammatory process in aging," Antioxidants and Redox Signaling, vol. 8, no. 3-4, pp. 572-581, 2006.
[12] H. Sies, "Role of metabolic $\mathrm{H}_{2} \mathrm{O}_{2}$ generation: redox signaling and oxidative stress," The Journal of Biological Chemistry, vol. 289, no. 13, pp. 8735-8741, 2014.

[13] H. Zou, E. Stoppani, D. Volonte, and F. Galbiati, "Caveolin1, cellular senescence and age-related diseases," Mechanisms of Ageing and Development, vol. 132, no. 11-12, pp. 533-542, 2011.

[14] A. R. J. Young, M. Narita, and M. Narita, "Cell senescence as both a dynamic and a static phenotype," Methods in Molecular Biology, vol. 965, pp. 1-13, 2013.

[15] D. Muñoz-Espín and M. Serrano, "Cellular senescence: from physiology to pathology," Nature Reviews Molecular Cell Biology, vol. 15, no. 7, pp. 482-496, 2014.

[16] Y. Qian and X. Chen, "Senescence regulation by the $\mathrm{p} 53$ protein family," Methods in Molecular Biology, vol. 965, pp. 37-61, 2013.

[17] C. M. Walsh, "Grand challenges in cell death and survival: apoptosis vs. necroptosis," Frontiers in Cell and Developmental Biology, vol. 2, article 3, 2014.

[18] J. Karch and J. D. Molkentin, "Regulated necrotic cell death: the passive aggressive side of bax and bak," Circulation Research, vol. 116, no. 11, pp. 1800-1809, 2015.

[19] F. Ding, Z.-W. Shao, and L.-M. Xiong, "Cell death in intervertebral disc degeneration," Apoptosis, vol. 18, no. 7, pp. 777-785, 2013.

[20] C. L. Le Maitre, A. J. Freemont, and J. A. Hoyland, "Accelerated cellular senescence in degenerate intervertebral discs: a possible role in the pathogenesis of intervertebral disc degeneration," Arthritis Research \& Therapy, vol. 9, no. 3, article R45, 2007.

[21] S.-W. Jeong, J.-S. Lee, and K.-W. Kim, "In vitro lifespan and senescence mechanisms of human nucleus pulposus chondrocytes," Spine Journal, vol. 14, no. 3, pp. 499-504, 2014.

[22] H. E. Gruber, J. A. Ingram, D. E. Davis, and E. N. Hanley Jr., "Increased cell senescence is associated with decreased cell proliferation in vivo in the degenerating human annulus," The Spine Journal, vol. 9, no. 3, pp. 210-215, 2009.

[23] L. Jiang, X. Zhang, X. Zheng et al., "Apoptosis, senescence, and autophagy in rat nucleus pulposus cells: implications for diabetic intervertebral disc degeneration," Journal of Orthopaedic Research, vol. 31, no. 5, pp. 692-702, 2013.

[24] G. Hou, H. Lu, M. Chen, H. Yao, and H. Zhao, "Oxidative stress participates in age-related changes in rat lumbar intervertebral discs," Archives of Gerontology and Geriatrics, vol. 59, no. 3, pp. 665-669, 2014.

[25] J.-S. Park, J.-B. Park, I.-J. Park, and E.-Y. Park, "Accelerated premature stress-induced senescence of young annulus fibrosus cells of rats by high glucose-induced oxidative stress," International Orthopaedics, vol. 38, no. 6, pp. 1311-1320, 2014.

[26] S. Roberts, E. H. Evans, D. Kletsas, D. C. Jaffray, and S. M. Eisenstein, "Senescence in human intervertebral discs," European Spine Journal, vol. 15, no. 3, pp. S312-S316, 2006.

[27] A. Dimozi, E. Mavrogonatou, A. Sklirou, and D. Kletsas, "Oxidative stress inhibits the proliferation, induces premature senescence and promotes a catabolic phenotype in human nucleus pulposus intervertebral disc cells," European Cells \& Materials, vol. 30, pp. 89-103, 2015.

[28] S. Suzuki, N. Fujita, N. Hosogane et al., "Excessive reactive oxygen species are therapeutic targets for intervertebral disc degeneration," Arthritis Research \& Therapy, vol. 17, article 316, 2015.

[29] L. A. Nasto, A. R. Robinson, K. Ngo et al., "Mitochondrialderived reactive oxygen species (ROS) play a causal role in aging-related intervertebral disc degeneration," Journal of Orthopaedic Research, vol. 31, no. 7, pp. 1150-1157, 2013. 
[30] L. A. Nasto, D. Wang, A. R. Robinson et al., "Genotoxic stress accelerates age-associated degenerative changes in intervertebral discs," Mechanisms of Ageing and Development, vol. 134, no. 1-2, pp. 35-42, 2013.

[31] Y.-J. Kuo, L.-C. Wu, J.-S. Sun, M.-H. Chen, M.-G. Sun, and Y.-H. Tsuang, "Mechanical stress-induced apoptosis of nucleus pulposus cells: An in vitro and in vivo rat model," Journal of Orthopaedic Science, vol. 19, no. 2, pp. 313-322, 2014.

[32] C.-Q. Zhao, L.-M. Wang, L.-S. Jiang, and L.-Y. Dai, “The cell biology of intervertebral disc aging and degeneration," Ageing Research Reviews, vol. 6, no. 3, pp. 247-261, 2007.

[33] S. Z. Wang, Y. F. Rui, J. Lu, and C. Wang, "Cell and molecular biology of intervertebral disc degeneration: current understanding and implications for potential therapeutic strategies," Cell Proliferation, vol. 47, no. 5, pp. 381-390, 2014.

[34] S. M. Richardson, A. Mobasheri, A. J. Freemont, and J. A. Hoyland, "Intervertebral disc biology, degeneration and novel tissue engineering and regenerative medicine therapies," Histology and Histopathology, vol. 22, no. 9, pp. 1033-1041, 2007.

[35] D. Sakai and G. B. Andersson, "Stem cell therapy for intervertebral disc regeneration: obstacles and solutions," Nature Reviews Rheumatology, vol. 11, no. 4, pp. 243-256, 2015.

[36] Z. Li, M. Peroglio, M. Alini, and S. Grad, "Potential and limitations of intervertebral disc endogenous repair," Current Stem Cell Research \& Therapy, vol. 10, no. 4, pp. 329-338, 2015.

[37] E. Sikora, "Rejuvenation of senescent cells-The road to postponing human aging and age-related disease?" Experimental Gerontology, vol. 48, no. 7, pp. 661-666, 2013.

[38] O. Krupkova, M. Sekiguchi, J. Klasen et al., "Epigallocatechin 3-gallate suppresses interleukin-1 $\beta$-induced inflammatory responses in intervertebral disc cells in vitro and reduces radiculopathic pain in rats," European Cells \& Materials, vol. 28, pp. 372-386, 2014.

[39] K.-Y. Ho, C.-C. Tsai, C.-P. Chen, J.-S. Huang, and C.-C. Lin, "Screening of Brazilian plant extracts for antioxidant activity by the use of DPPH free radical method," Phytotherapy Research, vol. 15, no. 2, pp. 127-130, 2001.

[40] A. Brandl, A. Hartmann, V. Bechmann, B. Graf, M. Nerlich, and P. Angele, "Oxidative stress induces senescence in chondrocytes," Journal of Orthopaedic Research, vol. 29, no. 7, pp. 11141120, 2011.

[41] Y. Ido, A. Duranton, F. Lan et al., "Acute activation of AMPactivated protein kinase prevents $\mathrm{H}_{2} \mathrm{O}_{2}$-induced premature senescence in primary human keratinocytes," PLOS ONE, vol. 7, no. 4, Article ID e35092, 2012.

[42] D. J. Kurz, S. Decary, Y. Hong, and J. D. Erusalimsky, "Senescence-associated $\beta$-galactosidase reflects an increase in lysosomal mass during replicative ageing of human endothelial cells," Journal of Cell Science, vol. 113, no. 20, pp. 3613-3622, 2000.

[43] D. Wlodkowic, J. Skommer, and Z. Darzynkiewicz, "Flow cytometry-based apoptosis detection," in Apoptosis: Methods and Protocols, vol. 559 of Methods in Molecular Biology, pp. 1932, Springer, Berlin, Germany, 2nd edition, 2009.

[44] C. L. Le Maitre, A. J. Freemont, and J. A. Hoyland, “The role of interleukin-1 in the pathogenesis of human intervertebral disc degeneration," Arthritis Research \& Therapy, vol. 7, no. 4, pp. R732-R745, 2005.

[45] J. A. Mengshol, M. P. Vincenti, C. I. Coon, A. Barchowsky, and C. E. Brinckerhoff, "Interleukin-1 induction of collagenase 3 (matrix metalloproteinase 13) gene expression in chondrocytes requires p38, c-Jun $\mathrm{N}$-terminal kinase, and nuclear factor $\kappa \mathrm{B}$ : differential regulation of collagenase 1 and collagenase 3 ," Arthritis and Rheumatism, vol. 43, no. 4, pp. 801-811, 2000.

[46] W. Brand-Williams, M. E. Cuvelier, and C. Berset, "Use of a free radical method to evaluate antioxidant activity," LWT_Food Science and Technology, vol. 28, no. 1, pp. 25-30, 1995.

[47] A. Munin and F. Edwards-Lévy, "Encapsulation of natural polyphenolic compounds; a review," Pharmaceutics, vol. 3, no. 4, pp. 793-829, 2011.

[48] H.-S. Kim, M. J. Quon, and J.-A. Kim, "New insights into the mechanisms of polyphenols beyond antioxidant properties; lessons from the green tea polyphenol, epigallocatechin 3gallate," Redox Biology, vol. 2, no. 1, pp. 187-195, 2014.

[49] P. Bellion, M. Olk, F. Will et al., "Formation of hydrogen peroxide in cell culture media by apple polyphenols and its effect on antioxidant biomarkers in the colon cell line HT-29," Molecular Nutrition and Food Research, vol. 53, no. 10, pp. 12261236, 2009.

[50] L. H. Long, M. V. Clement, and B. Halliwell, "Artifacts in cell culture: rapid generation of hydrogen peroxide on addition of (-)-epigallocatechin, (-)-epigallocatechin gallate, $(+)$-catechin, and quercetin to commonly used cell culture media," Biochemical and Biophysical Research Communications, vol. 273, no. 1, pp. 50-53, 2000.

[51] Q. M. Chen, V. C. Tu, J. Catania, M. Burton, O. Toussaint, and $\mathrm{T}$. Dilley, "Involvement of $\mathrm{Rb}$ family proteins, focal adhesion proteins and protein synthesis in senescent morphogenesis induced by hydrogen peroxide," Journal of Cell Science, vol. 113, part 22, pp. 4087-4097, 2000.

[52] H.-S. Kim, V. Montana, H.-J. Jang, V. Parpura, and J.-A. Kim, "Epigallocatechin gallate (EGCG) stimulates autophagy in vascular endothelial cells: a potential role for reducing lipid accumulation," The Journal of Biological Chemistry, vol. 288, no. 31, pp. 22693-22705, 2013.

[53] J. Zhou, B. L. Farah, R. A. Sinha et al., "Epigallocatechin3-gallate (EGCG), a green tea polyphenol, stimulates hepatic autophagy and lipid clearance," PLoS ONE, vol. 9, no. 1, Article ID e87161, 2014.

[54] N.-C. Yang, C.-H. Lee, and T.-Y. Song, "Evaluation of resveratrol oxidation in vitro and the crucial role of bicarbonate ions," Bioscience, Biotechnology and Biochemistry, vol. 74, no. 1, pp. 63$68,2010$.

[55] J. M. van Deursen, "The role of senescent cells in ageing," Nature, vol. 509, no. 7501, pp. 439-446, 2014.

[56] J. Campisi and F. D. di Fagagna, "Cellular senescence: when bad things happen to good cells," Nature Reviews Molecular Cell Biology, vol. 8, no. 9, pp. 729-740, 2007.

[57] G. H. Stein, L. F. Drullinger, A. Soulard, and V. Dulić, "Differential roles for cyclin-dependent kinase inhibitors p21 and p16 in the mechanisms of senescence and differentiation in human fibroblasts," Molecular and Cellular Biology, vol. 19, no. 3, pp. 2109-2117, 1999.

[58] W.-L. Yen and D. J. Klionsky, "How to live long and prosper: autophagy, mitochondria, and aging," Physiology, vol. 23, no. 5, pp. 248-262, 2008.

[59] G. L. Tipoe, T. M. Leung, E. C. Liong, T. Y. H. Lau, M. L. Fung, and A. A. Nanji, "Epigallocatechin-3-gallate (EGCG) reduces liver inflammation, oxidative stress and fibrosis in carbon tetrachloride $\left(\mathrm{CCl}_{4}\right)$-induced liver injury in mice," Toxicology, vol. 273, no. 1-3, pp. 45-52, 2010.

[60] D. Cia, J. Vergnaud-Gauduchon, N. Jacquemot, and M. Doly, "Epigallocatechin gallate (EGCG) prevents $\mathrm{H}_{2} \mathrm{O}_{2}$-induced 
oxidative stress in primary rat retinal pigment epithelial cells," Current Eye Research, vol. 39, no. 9, pp. 944-952, 2014.

[61] E. Cadenas and K. J. A. Davies, "Mitochondrial free radical generation, oxidative stress, and aging," Free Radical Biology \& Medicine, vol. 29, no. 3-4, pp. 222-230, 2000.

[62] T. Nakagawa and T. Yokozawa, "Direct scavenging of nitric oxide and superoxide by green tea," Food and Chemical Toxicology, vol. 40, no. 12, pp. 1745-1750, 2002.

[63] Y. M. Li, H. Y. E. Chan, Y. Huang, and Z. Y. Chen, "Green tea catechins upregulate Superoxide dismutase and catalase in fruit flies," Molecular Nutrition and Food Research, vol. 51, no. 5, pp. 546-554, 2007.

[64] Y. V. Simos, I. I. Verginadis, I. K. Toliopoulos et al., "Effects of catechin and epicatechin on superoxide dismutase and glutathione peroxidase activity, in vivo," Redox Report: Communications in Free Radical Research, vol. 17, no. 5, pp. 181-186, 2012.

[65] H. Maccario, N. M. Perera, A. Gray, C. P. Downes, and N. R. Leslie, "Ubiquitination of PTEN (phosphatase and tensin homolog) inhibits phosphatase activity and is enhanced by membrane targeting and hyperosmotic stress," The Journal of Biological Chemistry, vol. 285, no. 17, pp. 12620-12628, 2010.

[66] M. Osaki, M. Oshimura, and H. Ito, "PI3K-Akt pathway: its functions and alterations in human cancer," Apoptosis, vol. 9, no. 6, pp. 667-676, 2004.

[67] H. Tachibana, K. Koga, Y. Fujimura, and K. Yamada, "A receptor for green tea polyphenol EGCG," Nature Structural and Molecular Biology, vol. 11, no. 4, pp. 380-381, 2004.

[68] H. Pratsinis and D. Kletsas, "PDGF, bFGF and IGF-I stimulate the proliferation of intervertebral disc cells in vitro via the activation of the ERK and Akt signaling pathways," European Spine Journal, vol. 16, no. 11, pp. 1858-1866, 2007.

[69] D. Pasku, G. Soufla, P. Katonis, A. Tsarouhas, A. Vakis, and D. A. Spandidos, "Akt/PKB isoforms expression in the human lumbar herniated disc: correlation with clinical and MRI findings," European Spine Journal, vol. 20, no. 10, pp. 1676-1683, 2011.

[70] Z. Liu, K. Zhou, W. Fu, and H. Zhang, "Insulin-like growth factor 1 activates PI3k/Akt signaling to antagonize lumbar disc degeneration," Cellular Physiology and Biochemistry, vol. 37, no. 1, pp. 225-232, 2015.

[71] D. W. Wang, Z. M. Hu, J. Hao et al., "SIRT1 inhibits apoptosis of degenerative human disc nucleus pulposus cells through activation of Akt pathway," Age, vol. 35, no. 5, pp. 1741-1753, 2013.

[72] G. Pattappa, Z. Li, M. Peroglio, N. Wismer, M. Alini, and S. Grad, "Diversity of intervertebral disc cells: phenotype and function," Journal of Anatomy, vol. 221, no. 6, pp. 480-496, 2012. 


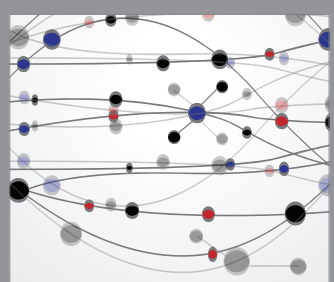

The Scientific World Journal
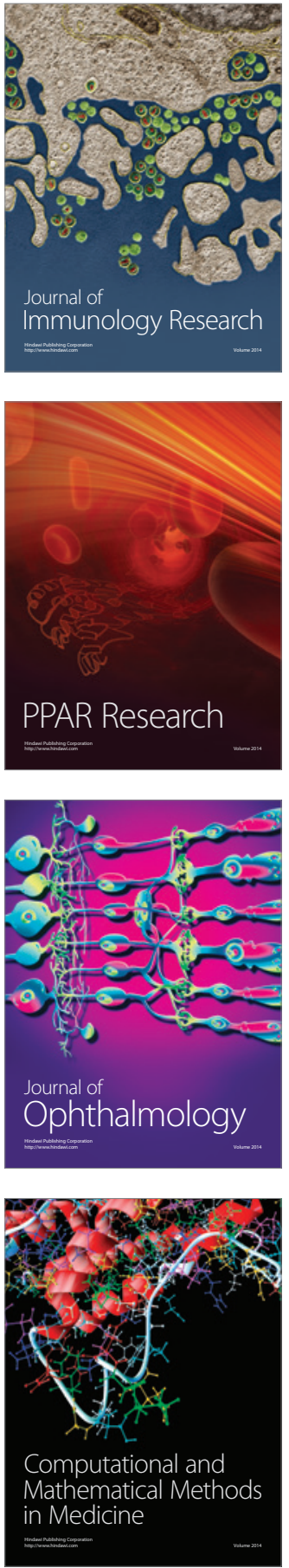

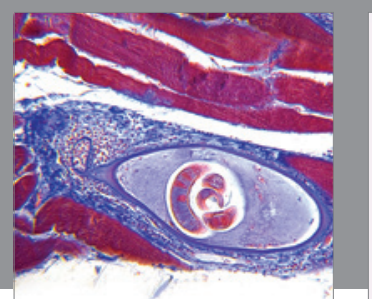

Gastroenterology Research and Practice

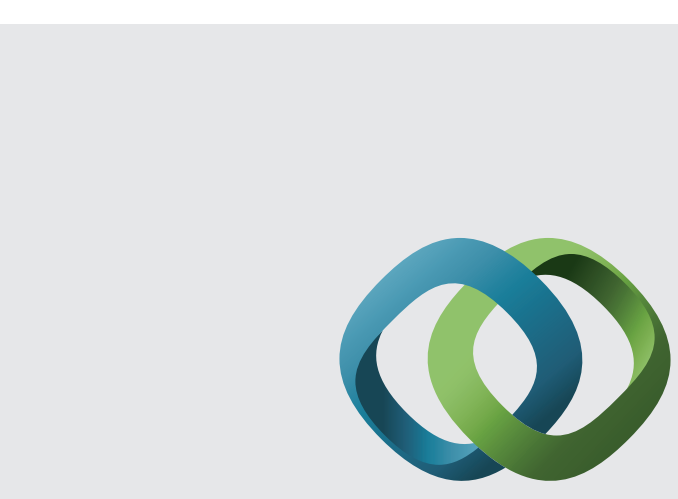

\section{Hindawi}

Submit your manuscripts at

http://www.hindawi.com
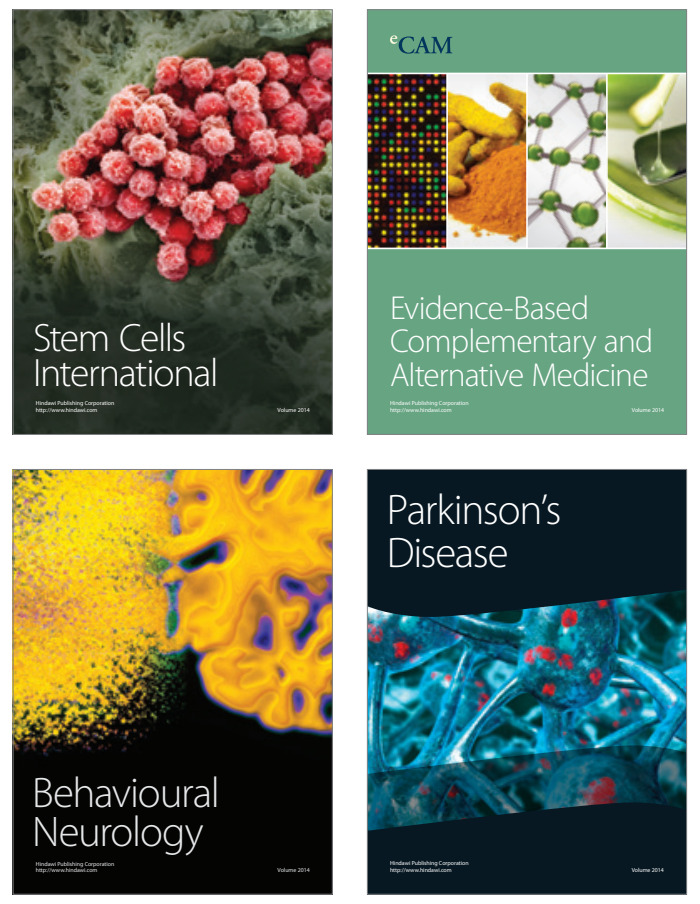
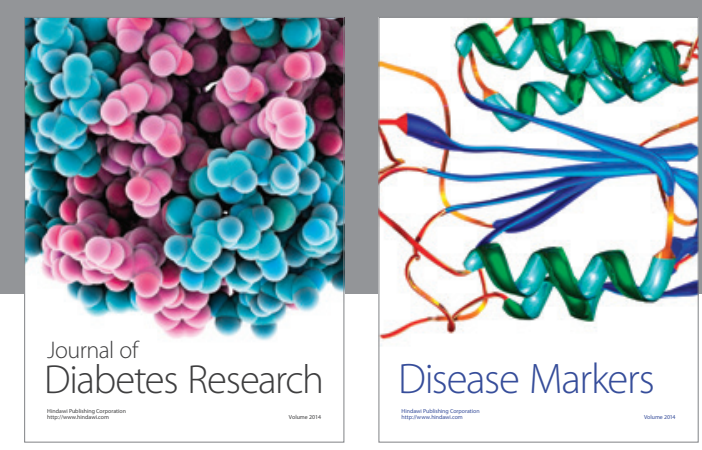

Disease Markers
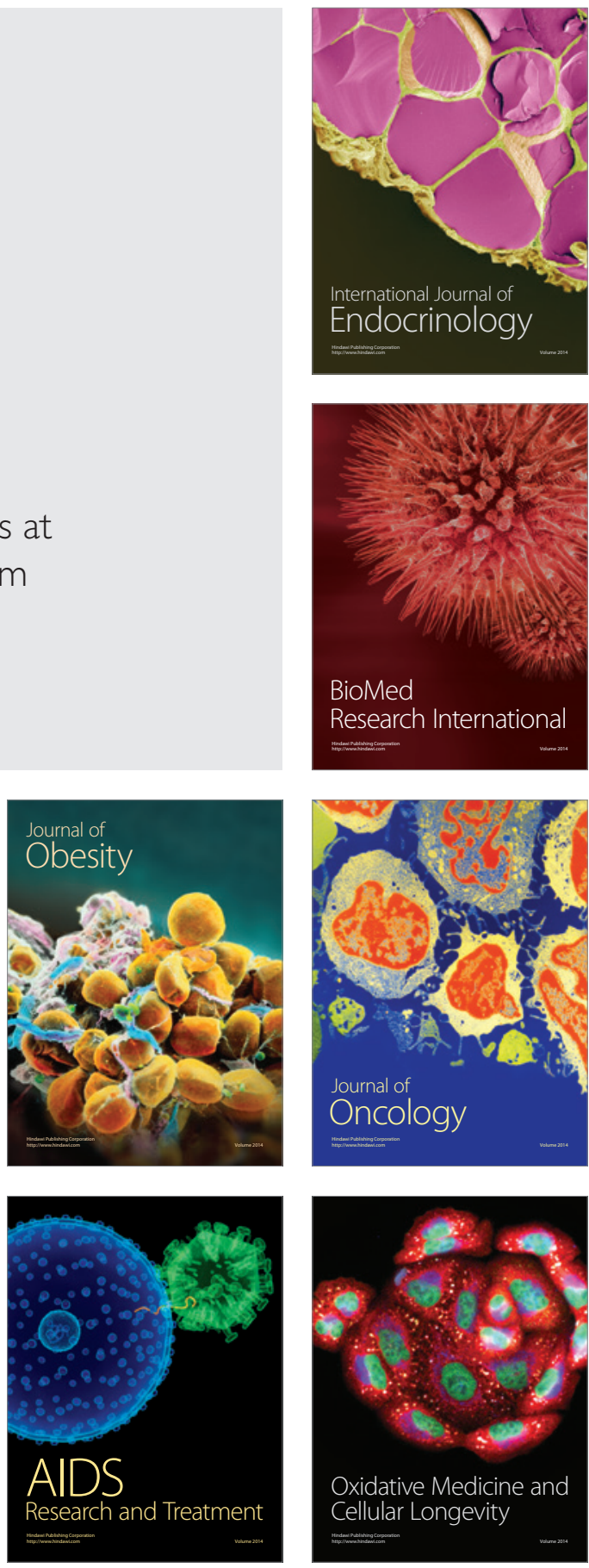